LBL- -31931

DE92 016358

\title{
DEVELOPMENT OF ADVANCED SECONDARY ZINC CELLS FOR POWER-SOURCE APPLICATIONS
}

\author{
Jenn-Shing Chen, Frank R. McLarnon and Elton J. Cairns \\ Energy \& Environment Division \\ Lawrence Berkeley Laboratory \\ Berkeley, CA 94720
}

December 1991

\author{
Sponsored by: \\ Defense Advanced Research Projects Agency (DoD) \\ Undersea Warfare Office \\ Submarine Technology Program \\ Mechanical and Electrical Area \\ for \\ Naval Sea Systems Command
}

This work was supported by the Defense Advanced Research Projects Agency, Undersea Warfare Office, Submarine Technology Program, under ARPA Order Number MIPR N0002490MP70004, through the U.S. Department of Energy under Contract No. DE-AC01-76SF00098. 


\section{INTRODUCTION}

The general advantages of $\mathrm{Zn} / \mathrm{AgO}$ batteries are high specific energy, high discharge rate capability, good charge acceptance, and low selî-discharge rate. However, the principal disadvantages of high cost and short cycle life lave limited the use of this battery to applications where high specific energy is the prime requisite, such as military and flight applications, portable electronic equipment, etc. The major objectives of this research project are to improve the $\mathrm{Zn} / \mathrm{AgO}$ cell cycle life and increase its performance. The redistribution of $\mathrm{Zn}$ active material (shape change) and the growth of $\mathrm{Zn}$ dendrites (which leads to cell shorting) have been identified as primary factors that limit the cycle-life performance of $\mathrm{Zn} / \mathrm{AgO}$ cells. These phenomena can be largely overcome by improvements in separator materials, and by additives to the electrode and electrolyte. Recent development work on $\mathrm{Zn} / \mathrm{AgO}$ cells has been concentrated in the area of $\mathrm{Zn}$ electrode and separator improvements to extend the lifetimes of cells $[1,2]$. It is well known that shape change and dendrite problems can be attributed to the high solubility of the $\mathrm{ZnO}$ discharge product in concentrated $\mathrm{KOH}$ electrolyte. Because the $\mathrm{ZnO}$ solubility depends strongly on the $\mathrm{KOH}$ concentration, a useful strategy is to operate the cell at as low a $\mathrm{KOH}$ concentration as can be tolerated by the positive electrode, and add indifferent supporting electrolyte to maintain acceptable ionic conductivity. Much research has successfully applied different altemative electrolytes, such as those containing fluoride, borate, phosphate, arsenate, and carbonate ions, to extend $\mathrm{Zn} / \mathrm{NiOOH}$ cell cycle life [3]. In this work, the primary objective was to determine the ability of reduced-zinc-solubility electrolytes to exiend the cycle life of $\mathrm{Zn} / \mathrm{AgO}$ cells by additives $\left(\mathrm{F}, \mathrm{CO}_{3}^{2-}, \mathrm{BO}_{3}^{3-}, \mathrm{PO}_{4}^{3-}\right.$; to the $\mathrm{KOH}$ electrolyte.

Many investigations have shown that the addition of $\mathrm{Ca}(\mathrm{OH})_{2}$ to the zinc clectrode can reduce the zincate-ion $\left[\mathrm{Zn}(\mathrm{OH})_{4}^{2-}\right]$ solubility and thereby improve the cycle life of $\mathrm{Zn} / \mathrm{NiOOH}$ sells [3 - 5]. When $\mathrm{Ca}(\mathrm{OH})_{2}$ is added to $\mathrm{ZnO}$ in alkaline electrolyte, an insoluble calcium zin- 
cate compound, $\mathrm{Ca}(\mathrm{OH})_{2} \cdot 2 \mathrm{Zn}(\mathrm{OH})_{2} \cdot 2 \mathrm{H}_{2} \mathrm{O}$, is fonned, thereby "trapping" the soluble $\mathrm{K}_{2} \mathrm{Zn}(\mathrm{OH})_{4}$ species [6]. Therefore, in this research the other objective is to determine the ability of calcium-containing zinc electrodes to extend the cycle life of $\mathrm{Zn} / \mathrm{AgO}$ cells.

\section{EXPERIMENTAL PROCEDURES}

In this work, two group of cells were tested. One group of cells was fabricated by BST Inc. and the other group was fabricated by LBL.

(1) Cell construction: All cells were designed to be silver-limiting in capacity, and deliver 5-Ah of rated capacity. The electrode sizes were $1.75^{\prime \prime} \times 1.4^{\prime \prime}$. In order to use the BST-fabricated AgO electrodes and cell cases, each cell contained six AgO electrodes, five full-capacity $\mathrm{Zn}$ electrodes, and two half-capacity $\mathrm{Zn}$ electrodes which were used as the outermost electrodes in the cell pack. The detailed cell-design calculations are presented in the Appendix. Table I summarizes the cell design for the BST and LBL cell groups. The BST cell group consisted of six BST-fabricated $\mathrm{Zn} / \mathrm{AgO}$ cells and the LBL cell group included five LBL-fabricated $\mathrm{Zn} / \mathrm{AgO}$ cells and two LBL-fabricated $\mathrm{ZnCa} / \mathrm{AgO}$ cells.

(2) Electrode specifications: All positive electrodes used in this work were furnished by BST, Inc. Each positive electrode contained $2.58 \mathrm{~g} \mathrm{Ag}$ applied on a $\mathrm{Ag}$ mesh current collector and was $-0.015^{\prime \prime}$ thick. In the BST-cell group, each full-capacity negative electrode contained 3.66 g ZnO applied to a $\mathrm{Ag}$ sheet current collector and was about $0.035^{\prime \prime}$ thick. In the LBL-cell group, the negative electrodes were prepared by a vacuum-table process [7]. Figure 1 shows the flow chart of this process for fabricating $\mathrm{Zn}$ electrodes. Each electrode contained $3.7 \mathrm{~g} \mathrm{ZnO}$ and was -0.048 " thick. The electrode compositions were: $93 \mathrm{wt} \% \mathrm{ZnO}$ (Mallinckrodt, Inc., Paris, KY, 99.9\% pure), 2 wt\% PbO (Mallinckrodt, inc., 99\% purc), 4 wt\% PTFE (E.I. Dupont de Nemours and Co., Wilmington, DE, Teflon Type 30 dispersion), and 1 wt\% Coronado newsprint (The Morilla Company, Los Angeles, CA). An 0.55-mm dia. Ag wire (Johnson Matthey/ 


\section{TABLE I : Zn/AgO Cell Design (silver-limiting capacity design)}

BST

$5 \mathrm{Ah}$

$1.75^{\prime \prime} \times 1.4 "$

$\mathrm{ZnO}=21.96 \mathrm{~g}$

$\mathrm{Ag}=15.48 \mathrm{~g}$

Ratio of active materials

Porosity (as metal based)

Cell pack

Separator system

Thickness for each plate

Total Thickness of Cell

$\mathrm{Ag}=55-60 \%$
LBL

$5 \mathrm{Ah}$

$1.75^{\prime \prime} \times 1.4^{\prime \prime}$

$\mathrm{Zn}-\quad \mathrm{ZnO}=22.2 \mathrm{~g}$

$\mathrm{ZnCa}-\mathrm{ZnO}=17.03 \mathrm{~g}$ $\mathrm{Ca}(\mathrm{OH})_{2}=5.17 \mathrm{~g}$

$\mathrm{Ag}=15.48 \mathrm{~g}$

$\mathrm{Mzn} /$ Mag Mass Ratio $=1.14 \quad \mathrm{Zn}-\quad$ Mzn $/$ Mag Ratio $=1.15$

$\mathrm{ZnCa}-\mathrm{Mzn} / \mathrm{Mag}$ Ratic $=0.88$

$\mathrm{ZnO}=50-60 \%$

$\mathrm{ZnO}=65-70 \%, \mathrm{ZnCa}=65-70 \%$

$\mathrm{Ag}=55-60 \%$

7 - ZnO, 6 - Ag, 12 - Sep.

7 - ZnO, 6- Ag, 12 - Scp.

$-/$ dexter $/ / 5^{*} \mathrm{cp} / \mathrm{cg} /$ pellon $/+$

$-/ 2^{*} \mathrm{cg} / / 5^{*} \mathrm{cp} / \mathrm{cg} / \mathrm{pcllon} /+$

$\mathrm{ZnO}=0.089 \mathrm{~cm}(35 \mathrm{mils})$

$\mathrm{ZnO}=0.122 \mathrm{~cm}(48 \mathrm{mils})$

$\mathrm{Ag}=0.038 \mathrm{~cm}(15 \mathrm{mils})$

$\mathrm{ZnCa}=0.175 \mathrm{~cm}(67 \mathrm{mils})$

$\mathrm{Ag}=0.038 \mathrm{~cm}$ (15 mils)

$1.453 \mathrm{crn}$ (572 mils)
$\mathrm{Zn}-\quad 1.686 \mathrm{~cm}$ (664 mils)

$\mathrm{ZnCa}-2.006 \mathrm{~cm}$ (790 mils) 
AESAR, Seabrook, NH) was spot-welded onto a Ag mesh current collector (Exmet Corp., Bridgeport, CT, 5Ag54-0). The $\mathrm{ZnCa}$ electrode was of the same initial mass as a full-capacity $\mathrm{Zn}$ electrode. Because a $25 \mathrm{~mol} \% \mathrm{Ca}(\mathrm{OH})_{2}$ (based on the $\mathrm{mol} \% \mathrm{Zn}$ and $\mathrm{Ca}$ in the uncycled electrode, not including inert materials) exhibited good cycle-life performance in $\mathrm{Zn} / \mathrm{NiOOH}$ cells [5], this composition was selected for use in the $\mathrm{ZnCa}$ agO cells. The density of $\mathrm{Ca}(\mathrm{OH})_{2}$ is $2.24 \mathrm{~g} / \mathrm{cm}^{3}$, which may be compared to $5.61 \mathrm{~g} / \mathrm{cm}^{3}$ for $\mathrm{ZnO}$. Therefore the $\mathrm{ZnCa}$ electrodes occupied a greater volume and thus required more binder and led to a thicker negative electrode. The electrode was $0.067^{\prime \prime}$ thick and contained $92 \mathrm{wt} \% \mathrm{ZnO}+\mathrm{Ca}(\mathrm{OH})_{2}, 2 \mathrm{wt} \% \mathrm{PbO}, 5$ wt\% PTFE and $1 \mathrm{wt} \%$ newsprint. The procedure for fabricating ZnCa electrodes was similar to that for zinc electrodes [5].

(3) Separator and wick: Each Ag electrode was wrapped with a layer of Pellon and Celgard separators, which were provided by BST company, and five layers of cellophane as the outer separator layers. The Pellon is used as a wick to keep the Ag electrodes wet with electrolyte and is a non-woven nylon material. The BST-group cells used one layer of Dexter paper (The Dexter Crop., Windsor Locks, CT, Grade: 10) around the Zn electrode, and the paper was sealed with cellophane tape (3M Corp., St. Paul, MN). In the LBL-group cells, two layers of Celgard 3401 (Celanese Fibers Corp., Summitt, NJ) microporous polypropylene sheet were heat-sealed around the zinc electrode.

(4) Electrolyte preparation: Table II lists the compositions of the various electrolytes that were tested. In order to simplify comparisons among these electrolytes, all of them were constituted to have a similar ionic strength $(1-15-16)$. The standard electrolyte was $45 \mathrm{wt} \% \mathrm{KOH}$ AnalaR grade solution (J.T. Baker Chemicals Co., Phillipsburg, NJ). The $\mathrm{K}_{2} \mathrm{CO}_{3}$ and $\mathrm{H}_{3} \mathrm{BO}_{3}$ were ACS reagent-grade chemicals (Fisher Scientific, NJ) and the $\mathrm{KF}$ and $\mathrm{K}_{3} \mathrm{PO}_{4}$ were Baker AnalaR grade chemicals. In order to avoid contamination by $\mathrm{CO}_{2}, 15 \mathrm{Mohm}-\mathrm{cm}$ or better 


\section{TABLE II : Electrolyte Compositions*}

BST-cell group :

Standard :

Alkaline-fluoride-carbonate :
$45 \% \mathrm{KOH}, \mathrm{ZnO}$ saturated

$34 \% \mathrm{KOH}, 3.6 \% \mathrm{KF}, 8.8 \% \mathrm{~K}_{2} \mathrm{CO}_{3}, \mathrm{ZnO}$ saturated

$17 \% \mathrm{KOH}, 8 \% \mathrm{KF}, 19 \% \mathrm{~K}_{2} \mathrm{CO}_{3}, \mathrm{ZnO}$ saturated

$25.2 \% \mathrm{KOH}, 12.4 \% \mathrm{KF}, 8.8 \% \mathrm{~K}_{2} \mathrm{CO}_{3}, \mathrm{ZnO}$ saturated

$25.6 \% \mathrm{KOH}, 3.9 \% \mathrm{KF}, 15.9 \% \mathrm{~K}_{2} \mathrm{CO}_{3}, \mathrm{ZnO}$ saturated

LBL-cell group :

Standard :

Alkaline-fluoride :

Alkaline-carbonate :

Alkaline-borate :

Alkaline-phosphate :

$45 \% \mathrm{KOH}, \mathrm{ZnO}$ saturated

$37 \% \mathrm{KOH}, 9 \% \mathrm{KF}, \mathrm{ZnO}$ saturated

$38 \% \mathrm{KOH}, 8 \% \mathrm{~K}_{2} \mathrm{CO}_{3}, \mathrm{ZnO}$ saturated

$39 \% \mathrm{KOH}, 5 \% \mathrm{~K}_{3} \mathrm{BO}_{3}$, $\mathrm{ZnO}$ saturated

$39 \% \mathrm{KOH}, 6 \% \mathrm{~K}_{3} \mathrm{PO}_{4}, \mathrm{ZnO}$ saturated

* The wt\% shown in the table are the compositions before addition of $\mathrm{ZnO}$ to the electrolyte 
deionized water was used. Following preparation of each solution, $\mathrm{ZnO}$ was added in sufficient quantity to saturate the electrolyte.

(5) Cell assembly: The cell pack (separator/electrode) assembly was designed for split-wrap [2] configuration. The positive electrodes were wrapped in pairs and the tube thus formed was folded at the center line so that two electrodes were enclosed in one bag and the negative electrodes were individually bagged with the bottoms sealed. The cell cases were made from polysulfone (for the BST-group cells) and from acrylic (for the LBL-group cells). In order to analyze the behavior of individual electrodes, a reference electrode was used for every cell except $\mathrm{B} 1$ and $\mathrm{B} 2$. $\mathrm{A} \mathrm{Hg} / \mathrm{HgO}$ clectrode located in a separate reference compartment that was filled with the same electrolyte was used as the reference electrode. The cell pack was placed in a tightly fitting cell case, and each cell was filled with $20 \mathrm{ml}$ of electrolyte. The rate at which the electrodes absorbed the electrolyte was slow because five layers of cellophane were used, and the cell pack was under pressure. The electrode soak time was about 5 days. The cell was vented and an Ascarite column was attached to prevent $\mathrm{CO}_{2}$ from entering the cell.

(6) Cell cycling tests: Cells were cycled under controlled charge and discharge regimens using a combination of analog and digital equipment, which has been described in detail in Ref. [8]. All cells were tested at constant current. Prior to beginning regular cycle testing, two formation cycles were performed in order to render the cell active. The first formation cycle employed a $0.5-\mathrm{A}$ charge to a $2.2-\mathrm{V}$ cell cut-orf voltage, followed by a $0.5-\mathrm{A}$ discharge to a $1.1-\mathrm{V}$ cut-off, The second formation cycle employed a 0.5 -A charge to a $2.01-\mathrm{V}$ cell cut-off voltage, followed by a $0.5-\mathrm{A}$ discharge to a $1.1-\mathrm{V}$ cell cut-off voltage. Standard cycle testing used $0.5-\mathrm{A}$ charge current to a $2.01-\mathrm{V}$ cell cut-off voltage and a 1.0 -A discharge current to a $1.1-\mathrm{V}$ cell cut-off voltage. An open-circuit period of 30 minutes was implemented at the end of each half-cycle.

(7) Analysis of cycled cells: After cells completed cycling, the $\mathrm{Zn}$ electrodes were examined to 
determine extent of the shape charge, and each separator layer was analyzed for Ag content. Zinc electrode shape change was determined by analysis of x-ray photographs, which were obtained using a $60-\mathrm{KeV} \mathrm{x}$-ray beam, and an exposure of $100 \mathrm{mAs}$. Scanning electron microscopy (SEM) was employed for qualitative analysis of the zinc electrode morphology. An AMR model $1000 \mathrm{SEM}$ was used for this purpose. The Ag content of the separator was deteremined by Volhard methods [9]. Samples of the separators were cut from the electrodes. Each sample was cleaned several times with distilled water, and then placed in a $250-\mathrm{ml}$ beaker with $25 \mathrm{ml}$ of 42 wt\% nitric acid. The beaker was heated for about 30 minutes to aid in the dissolution of the $\mathrm{Ag}$ from the separator sample. The resulting solutions were titrated with $0.1 \mathrm{~N}$ or $0.01 \mathrm{~N}$ ammonium thiocyanate (Baker AnalaR grade) using ferric ammonium sulfate (Fisher Scientific ACS grade) as an indicator. The initial yellow color changed to reddish-brown at the end point. The tensile strength of the cellophane separators was measured in order to determine the effect of electrolyte composition on separator tensile strength. Measurements were made using an Instron electro-hydraulic tensile tester model 1321.

\section{RESULTS AND DISCUSSION}

A total of 6 cells in the BST-cell group were subjected to cycle-life testing to evaluate standard electrolytes (as a baseline test for comparison purposes), and the alkaline-fluoride and alkaline-carbonate electrolytes listed in Table II. Two cells [designed B1 and B1(2)] contained standard clectrolyte $(45 \% \mathrm{KOH})$ and four cells [designed B-2 through B-5] contained 34 wt\% $\mathrm{KOH} / 3.6 \mathrm{wt} \% \mathrm{KF} / 8.8 \mathrm{wt} \% \mathrm{~K}_{2} \mathrm{CO}_{3}, 25.6 \mathrm{wt} \% \mathrm{KOH} / 3.9 \mathrm{wt} \% \mathrm{KF} / 15.9 \mathrm{wt} \% \mathrm{~K}_{2} \mathrm{CO}_{3}, 17 \mathrm{w} / \%$ $\mathrm{KOH} / 8 \mathrm{wt} \% \mathrm{KF} / 19 \mathrm{wt} \% \mathrm{~K}_{2} \mathrm{CO}_{3}$, and $25.2 \mathrm{wt} \% \mathrm{KOH} / 12.4 \mathrm{wt} \% \mathrm{KF} / 8.8 \mathrm{wt} \% \mathrm{~K}_{2} \mathrm{CO}_{3}$, respectively. Five cells of the LBL-cell group were subjected to cycle-life testing to cvaluate the standard and alkaline-fluoride, -carbonate, -borate, -phosphate electrolytes listed in Table II. These cells [designed Li through L5] contained standard electrolyte $(45 \% \mathrm{KOH}), 37 \mathrm{wt} \% \mathrm{KOH} / 9 \mathrm{wt} \%$

$\mathrm{KF}, 38 \mathrm{wt} \% \mathrm{KOH} / 8 \% \mathrm{~K}_{2} \mathrm{CO}_{3}, 39 \mathrm{wt} \% \mathrm{KOH} / 5 \mathrm{wt} \% \mathrm{~K}_{2} \mathrm{BO}_{3}$, and $39 \mathrm{wt} \% \mathrm{KOH} / 6 \mathrm{wt} \% \mathrm{~K}_{3} \mathrm{PO}_{4}$, 
respectively. Two cells with $\mathrm{ZnCa}$ negative elecirodes in the LBL-cell group [designed as $\mathrm{C1}$ and $\mathrm{Cl}(2)$ ] were used to evaluate $\mathrm{ZnCa}$ electrode performance in standard $45 \% \mathrm{KOH}$ electrolyte. The following results that show the cell capacity retention data in this work are based on the cell rated capacities, i.e. $5 \mathrm{Ah}=100 \%$ capacity, regardless of the initial (maximum) capacity exhibited by the cell. Cells B1 and L1 with standard electrolyte were used as base-line control cells in the BST-cell and LBL-cell group.

Figure 2 shows a plot of capacity vs cycle number for the BST-cell group. All of the cells had at least $98 \%$ coulombic efficiency for all standard cycles. However cells with additives in the electrolyte exhibited a lower capacity than the cell with standard $45 \mathrm{w} \% \mathrm{KOH}$ electrolyte. Increasing amounts of $\mathrm{KF}$ added to $\mathrm{KOH}$ electrolyte resulted in a lower capacity than that exhibited by the control cell B1. The capacity of Cell B1 reached its maximum value $(-115 \%)$ after about 20 cycles, and the capacity of Cell B1 remained above $80 \%$ of its initial value until it dropped to $77 \%$ after 135 cycles, followed by a sharp drop to $19 \%$. Figures 3 - 7 show cell voltage $v s$ time plots for various cycles for Cells B1 - B5 and B1(2). The shape of the discharge curve consists of a declining portion during the first 1.5 - 2 hours of discharge followed by a flat plateau for the next time period, after which the cell voltage drups rapidly to the $1.1-\mathrm{V}$ cell cutoff voltage (when the discharge capacity is nearly exhausted). The charge curve also shows two steps (plateaus) before the charge cut-off voltage $(2.01 \mathrm{~V})$ is reached, and the first plateau (the formation of $\mathrm{Ag}_{2} \mathrm{O}$ ) is shorter than the second one (the formation of $\mathrm{AgO}$ ). The average charge voltage is about $1.88 \mathrm{~V}$, and the average discharge voltage is about $1.53 \mathrm{~V}$. The shapes of the discharge curves indicate that the Ag electrode was capacity-limiting throughout all of the test regimens. Also, cells with additives have a lower capacity, which can be attributed to the bchavior of the $\mathrm{Ag}$ electrode in the presence of the modified electrolytes. Even though Cell B1 exhibits a higher capacity, the discharge plateau shows an unusual declining slope decline (see Fig. 3). Figure 8 shows coulombic efficiencies vs cycle number for Cells B1 and B2. The 
coulombic efficiencies were at least $98 \%$ for all standard cycles. Open-circuit stand tests (to evaluate charge retention) for Cell B1 were conducted at cycles 46,47 , and 103 for 84,87 and 73 hours, respectively. The cell maintained its normal coulombic efficiency (>98\%) during these tests. However, the coulombic efficiency declined to about $92 \%$ after a 52 -hour opencircuit test at cycle 125 , and the coulombic efficiency fell below $25 \%$ after cycle 135 . The lower coulombic efficiency at the end of cell life suggests that the failure of Cell B1 can be attributed to zinc dendrites (hard short). Cell B2 retained more than $82 \%$ of its initial capacity after 60 cycles, but its coulombic efficiency dropped to about $75 \%$ (sec Fig. 8). Also, the charge voltage was "choppy" near the cut-off voltage (see Fig. 4). The choppy cell voltage suggests dendrite formation, and dendrite growth was indeed observed around the negative electrodes.

Figures 9 and 10 show the capacity and coulombic efficiency $v$ s cycle number for Cells B1 and B1(2). Cell B1(2) was intended to replicate the long-lived and high-capacity "baseline" Cell B1. However, Cell B1(2) could not maintain high capacity $(>95 \%)$ after 40 cycles, and dropped to $73 \%$ capacity at cycle 65 . Obviously, Cell B1(2) exhibited a lower capacity than that of Cell B1, although both cells had similar coulombic efficiency (at least 98\%, see Fig. 10).

Figure 11 shows capacity vs cycle number for Cells L1 - L5. Similar to the results with the BST-cell group, cells with different electrolyte additives (fluoride, carbonate, borate, and phosphate) showed generally lower capacities, especially those with fluoride and phosphate additives. Figures 12 - 16 show cell voltages and electrode potentials for the LBL-cell group. All cells exhibit the expected shapes of charge and discharge curves. However, the plots clearly show that the Ag electrode limits the capacity of all lower-capacity cells. This phenomenon can be attributed to the formation of inorganic salts at the $\mathrm{Ag}$ electrode (eg $\mathrm{AgF}$ or $\mathrm{AgF}_{2}, \mathrm{AgPO}_{4}$, etc) resulting in Ag active materials loss. The "baseline" Cell $\mathrm{L} 1$ reached 115 cycles and maintained $80 \%$ of its original capacity. Figures 17 and 18 show capacity and coulombic efficiency 
vs cycle number for Cells $\mathrm{L} 1$ and $\mathrm{Cl}$. Both cells were filled with $45 \mathrm{wt} \% \mathrm{KOH}$ electrolyte and employed the same separator system, and differed only in the composition of the $\mathrm{Zn}$ electrode. However, Cell $\mathrm{Cl}$ with $\mathrm{Ca}(\mathrm{OH})_{2}$ in the zinc electrode showed higher capacity and longer cycle-life. Obviously, the additive $\mathrm{Ca}(\mathrm{OH})_{2}$ has a positive effect in $\mathrm{Zn} / \mathrm{AgO}$ cells. Both cells showed normal coulombic efficiencies ( $>98 \%)$. The total delivered capacity was 538 Ah for Cell L1 and $598 \mathrm{Ah}$ for Cell $\mathrm{C} 1$ for the first 120 cycles, over which both of cells maintained $>80 \%$ of rated capacity. This difference in performance can be attributed to the addition of $\mathrm{Ca}(\mathrm{OH})_{2}$ to the $\mathrm{Zn}$ electrode, which results in the formation of an insoluble $\mathrm{Ca}(\mathrm{OH})_{2} \cdot 2 \mathrm{Zn}(\mathrm{OH})_{2} \cdot 2 \mathrm{H}_{2} \mathrm{O}$ complex (6), which lowers the concentration of soluble zincate species and causes somewhat different cell behavior. Especially at higher $\mathrm{KOH}$ concentration, the calcium-zincate decomposition rates are relatively fast (10).

Figure 19 shows cell voltage and electrode potentials for different cycles for $\mathrm{Cell} \mathrm{C} 1$. The first charge plateau (the formation of $\mathrm{Ag}_{2} \mathrm{O}$ ) was longer than typical and became shorter with increasing cycle number. The unusually long first charge plateau results in higher capacity and lower average charge voltage. Also, the flat discharge plateau was longer than typical, and the average discharge voltage was lower. During the oxidation of $\mathrm{Ag}$ electrodes, the formation of $\mathrm{Ag}_{2} \mathrm{O}$ and $\mathrm{AgO}$ films results in two charge plateaus, where the second charge plateau (the formation of $\mathrm{AgO}$ film) is longer than the first one (the formation of $\mathrm{Ag}_{2} \mathrm{O}$ film). At moderate current densities, both processes are about $100 \%$ efficient (11). Therefore, the length of the plateaus is a function of the relative thicknesses of the oxide films. Generally, the thickness of the film depends on the current density, electrolyte concentration, and physical state of that electrode (12). The faster calcium-zincate decomposition rate [compared to the decomposition rate of $\mathrm{K}_{2} \mathrm{Zn}(\mathrm{OH})_{4}$ ] in higher $\mathrm{KOH}$ concentration electrolytes facilitates $\mathrm{OH}^{-}$transport from the $\mathrm{Zn}$ electrode to the Ag electrode, and can thereby result in the longer first charge plateau (or thicker $\mathrm{Ag}_{2} \mathrm{O}$ film). However, after a few cycles, the deposition of $\mathrm{Ag}$ on the separator may hinder $\mathrm{OH}^{-}$ 
ion transport from the $\mathrm{Zn}$ to the Ag electrode. Also, active material loss in electrodes results in a shorter charge plateau and lower capacity. Open-circuit stand tests (to evaluate charge retention) for Cell $\mathrm{Cl}$ were conducted at cycles 59,76 and 180 for 72,48 and 58 hours, respectively. The cell maintained its normal coulombic efficiency ( $>98 \%$ ) during these tests. Unlike Cell B1, Cell C1 did not exhibit dendrite problems, even after 180 cycles.

Cell $\mathrm{Cl}(2)$ was intended to replicate the long-lived and high-capacity "base-line" Cell $\mathrm{Cl}$. Both cells had the same cell pack design, and differed only in the thickness of the respective cell cases. Cell $\mathrm{C} 1(2)$ had a $0.040^{\prime \prime}$-thicker cell case than Cell C1. Figurc 20 shows the capacity $v$ cycle number plots for Cells $\mathrm{C} 1$ and $\mathrm{C} 1(2)$. Both cells showed a similar maximum capacity of $-122 \%$ of the rated value between cycles 15 and 20 . Because Cell Cl(2) showed only $90 \%$ of rated capacity after its formation cycles, the capacity of Cell $\mathrm{C} 1(2)$ was lower than that of Cell $\mathrm{C} 1$, however the the shapes of capacity curves were similar.

Figure 21 shows capacity vs' cycle number for Cells B1, L1 and C1. All three cells were constructed in a similar manner, and the major difference among these cells is the composition and fabrication of the $\mathrm{Zn}$ electrodes. The $\mathrm{Zn}$ electrodes utilized in Cell B1 were made by BST, Inc. and LBL fabricated the $\mathrm{Zn}$ electrodes used in in Cells $\mathrm{L} 1$ and $\mathrm{C} 1 . \mathrm{Ca}(\mathrm{OH})_{2}$ was added to the $\mathrm{Zn}$ electrodes only in Cell $\mathrm{Cl}$, as described above. Also, one layer of Dexter paper was used around the Zn electrode in Cell B1, and two layers of Celgard 3401 were used in Cells L1 and C1. Dendrite problems were the cause of failure only in Cell B1 (after 136 cycles). Apparently, the separator Celgard 3401 has the beneficial effect of preventing dendrite growth in these cells. Cells B1 and C1 showed comparable total delivered capacity ( $-656 \mathrm{Ah})$ and Cell L1 exhibited a somewhat lower total delivered capacities $(\sim 601 \mathrm{Ah})$, after the cells completed 136 cycles before Cell $\mathrm{B} 1$ failed. Even though Cells $\mathrm{B} 1$ and $\mathrm{Cl}$ show comparable capacities, Cell $\mathrm{C} 1$ exhibited higher capacities early in life and a longer cycle life. 
The Ag content of the separators was determined after the cells completed their cycling tests. Figures 22 - 27 show the Ag content of the separator system for different cells for various completed cycle numbers. All cells snowed the highest $\mathrm{Ag}$ content at the first layer of cellophane adjacent to the $\mathrm{Ag}$ electrode. Cells $\mathrm{Bl}$ and $\mathrm{Cl}$, after completing 136 and 185 cycles, respectively, showed that Ag penetration became progressively smaller through one layer of Pellon wick, one layer of Celgard and three layers of cellophane (see Figs. 22 and 27). Cells B2 and $\mathrm{B} 3$, which had lower $\mathrm{KOH}$ concentration, showed higher $\mathrm{Ag}$ contents on the separator layers, compared to Cell B1 (see Figs. 23 and 24 , This observation can be attributed to a higher Ag solubility and greater separator degradation rate for Cells B2 and B3. Table III shows the results of the tensile-strength test of cellophanes in different electrolytes for different periods of time. These results show that tensile strength decreased with lower $\mathrm{KOH}$ concentrations.

\section{TABLE III : Tensile Strength* of Cellophane}

\section{Sample Condition}

dry

wet
Breaking Load (lbs.)

5.3

0.72

Hydrolysis conditions ... $45 \% \mathrm{KOH}+$ satd. $\mathrm{ZnO} \& \mathrm{AgO}$ at $90^{\circ} \mathrm{C}$

24 hrs.

0.48

$48 \mathrm{hrs}$.

0.23

72 hrs.

0.07

rydrolysis conditions -- $39 \% \mathrm{KOH}+5 \% \mathrm{~K}_{2} \mathrm{BO}_{3}+$ satd. $\mathrm{ZnO} \& \mathrm{AgO}$ at $90{ }^{\circ} \mathrm{C}$
$24 \mathrm{hrs}$
0.41
48 hrs
0.1

Hydrolysis conditions -.. $38 \% \mathrm{KOH}+8 \% \mathrm{~K}_{2} \mathrm{CO}_{3}+$ satd. ?nO \& $\mathrm{AgO}$ at $90^{\circ} \mathrm{C}$ $24 \mathrm{hrs}$

\footnotetext{
* Loading Speed $=4 \mathrm{in} . / \mathrm{min}$.

Loading Samp:le $=4^{\prime \prime} \times 3 / 8^{\prime \prime}$
} 
Figure 28 shows $x$-ray images of uncycled zinc and zinc-calcium elec' odes. As can be seen, there is a uniform distribution of active materials over the Ag mesh current collectors. Xray images of numerous zinc electrodes were recorded to assess the rate and extent of zinc material redistribution (shape change) that accompanied cell cycling. Figures 29 and 30 show $x$-ray images of Cells B1, L1, C1, C1(2), L3, and LA after the cells had completed the numbers of cycles indicated in the figure caption. All cells were examined in the discharged state, i.e. after discharging each cell to the 1.1-V cut-off voltage. Both Figures 29 and 30 show, from left 1.o right, zinc electrode \#1 (a zinc electrode nearest to the cell container), zinc electrode $\# 2$, zinc electrode \#3 and zinc electrode \#4 (at the center of the cell pack). The cell shape-change patterns were symmetrical, i.e. the shape change pattern for zinc electrode \#7 was similar to that of zinc electrode \#1, the shape-change pattern of zinc electrode \#6 was similar to that of zinc electrode $\$ 2$, and so on. Cell BI showed a modest extent of shape change after attaining 136 cycics. The LBL-cell group [L1, C1, C1(2), L3, and L4] showed more-extensive shape change, and the shape-change patterns were rather similar to one another. Three types of morphology can be easily distinguished in the electrodes of the LBL-group cells: (i) a dense, compact zinc area at the bottoms of the electrodes, (ii) "islands" of zinc, and (iii) areas of nearly barc current collector with a slight residual anount of zinc. The outermost zinc electrode (zinc electrode \#1), which started cycling with half the capacity of its neighbors, exhibited mostly areas of neariy bare current collector and areas of dense, compact zinc. The island areas were more commonly found in the inner zinc electrodes (i.e. \#2 through \#6).

Other investigators $[3-5]$ have shown that additions of calcium can reduce the rate and extent of zinc electrode shape change, particularly in electrolytes of low-10-moderate $\mathrm{KOH}$ concentration, because of the formation of a caicium-zincate complex. Cell $\mathrm{Cl}$ exhibited extensive zinc electrode shape change, which leads one to suspect that the formation of the calcium-zinc complex was inhibited by the high $(45 \mathrm{wt} \%) \mathrm{KOH}$ coticentration [this turns out not to be the 
case - see below]. It appears to be more likely that the use of Dexter paper around the zinc electrodes in the BST cells inhibits the rate and exten of shape change, at least in $45 \mathrm{wt} \% \mathrm{KOH}$ electrolyte (see Fig. 29 ), compared to the LBL cells which employed Celgard separator next to the zinc electrodes. Different types of Ag-electrode current collectors were used in the LBLgroup and BST-group cells (mesh and sheet, respectively), however it is less likely that this difference is the root cause of the dramatically different shape change patterns.

The three distinct areas of the various zinc electrode samples (nearly bare current collector, island, and dense areas) harvested from Cells B1, L1 and $\mathrm{Cl}$ were examined microscopi. cally using a SEM. This exanination permits an assessment of the physical and chemical variations over microscopic areas of the electrodes. Figures 31-33 show the morphologies of selected areas in zinc electrodes fronı Cells B1, L1 and C1, respectively. In Cell B1 (see Fig. 31a) the uppermost area of the electrode (mainly bare current ccllector) exhibited needle-like metallic $\mathrm{Zn}$ on the surface, which led the formation and growth of $\mathrm{Zn}$ dendrites. The lower area of tre electrode (Fig. 31b) contained typical porous zinc/zinc oxide material. In Cell L1 (Fig. 32), the island area contaired porous zinc/zinc oxide material, and the bare current collector and dense areas contained very compact material (Figs. 32a and 32c), however some of the material in these areas has a porosity similar to that of the island area. In Cell C1 (Fig. 33), all three areas exhibited crystals typical of the calcium zincate complex. In particular, the island area (Fig. 33b) contained large amounts of these diamond-shape crystals. The bare current collector and dense arcas (Figs. 33a and 33c) contained fewer diamond-shaped crystals, and in the dense area hexagonal crystals were found. Obviously, the morphology of calcium-zinc clectrodes differs oframatically from that of the typical zinc electrode, and the use of $45 \mathrm{wt} \% \mathrm{KOH}$ electrolyte does not prevent the formation of calcium-zincate crystals. The good cycle-life performance of Cell $\mathrm{Cl}$ may be attributed the formation of the calcium-zinc complex, however the great extent of shape change suggests that even better performance could be realized, perhaps 
by improving the wetting characteristics of the electrode.

Table IV lists cycle-life performance data for the three groups of 5-Ah $\mathrm{Zn} / \mathrm{AgO}$ cells that were cycled. Included in this table are values of the capacity loss rate (expressed as \%/cycle, based on the initial cell capacity) and the average delivered capacity per cycle, both based on the cell performance before its capacity dropped to 4.0 Ah. These "figures of merit" illustrate the superior cycle-life performance of the calcium-containing $\mathrm{Zn} / \mathrm{AgO}$ cells. 


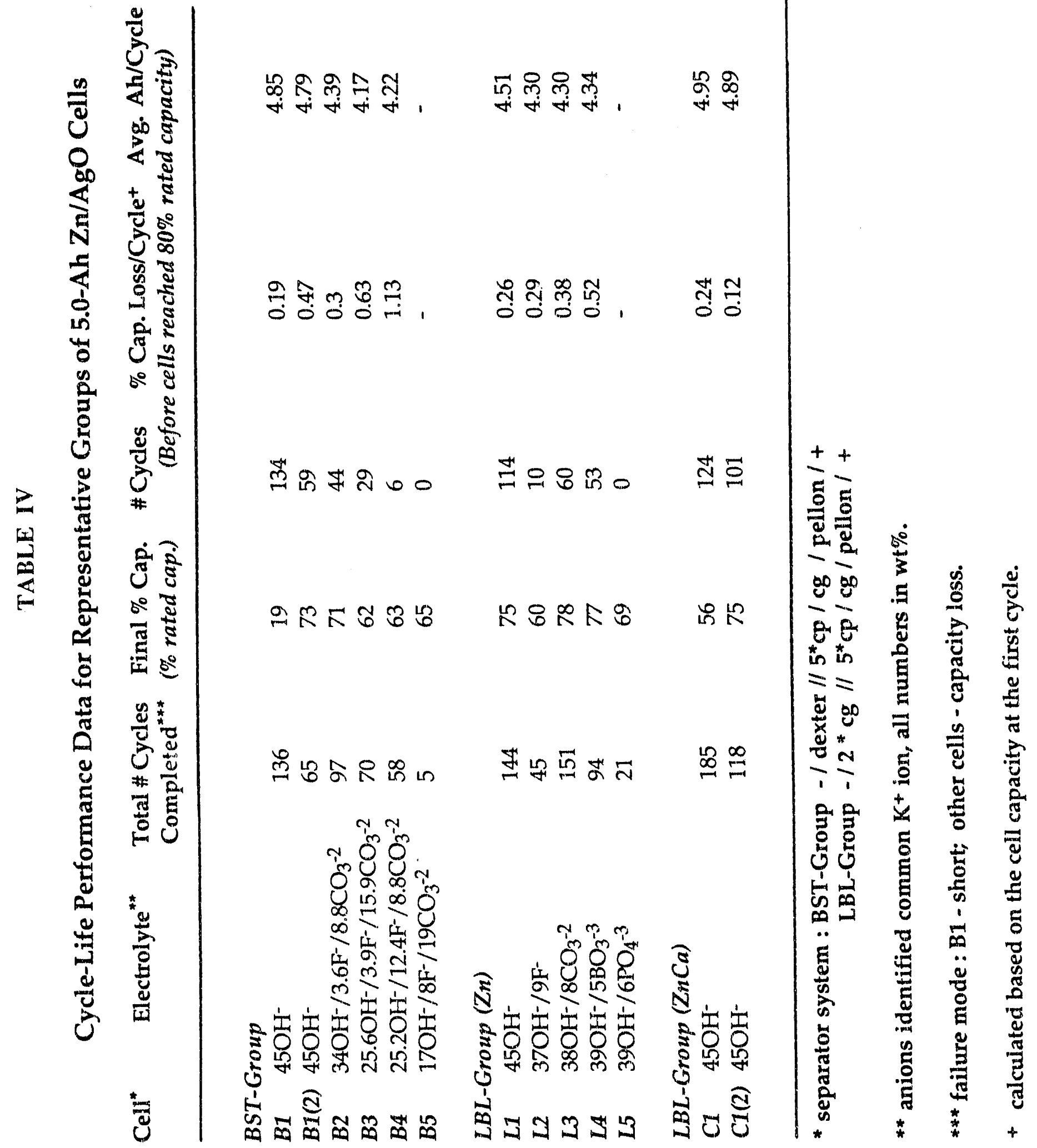




\section{CONCLUSIONS}

1. The ability of reduced-zinc solubility electrolytes, prepared by adding $\mathrm{F}, \mathrm{CO}_{3}^{2-}, \mathrm{BO}_{3}^{3-}$ and $\mathrm{PO}_{4}^{3-}$ to $\mathrm{KOH}$ electrolyte, to extend the cycle life of $\mathrm{Zn} / \mathrm{AgO}$ cells was examined. It would appear that all of the anion additives to $\mathrm{KOH}$ electrolytes result in lower capacities. Lower capacities can be attributed to poor Ag electrode behavior, which could be due to the formation of inorganic salts, e.g. $\mathrm{AgF}, \mathrm{AgF} 2, \mathrm{Ag}_{2} \mathrm{CO}_{3}, \mathrm{Ag}_{2} \mathrm{BO}_{3}$ and $\mathrm{Ag}_{3} \mathrm{PO}_{4}$, that cause active materials loss.

2. The calcium-containing zine electrode was found to significantly improve the performance of the $\mathrm{Zn} / \mathrm{AgO}$ cell by promoting higher capacities, especially over the initial 20 cycles. The higher capacities can be attributed to the formation of a calcium-zincate complex, crystals of which were found in the cycled zinc clectrodes. This result bears further investigation.

3. In the analysis of the silver content of the separator, results showed that the Ag content became progressively smaller through a single layer of Pellon and Celgard and three layers of cellophane. Cellophane was a good material to prevent Ag penetration. The results of scparator tensile strength measurements showed that the tensile strength of cellophane decreased with lower KOH concentration.

4. Because $\mathrm{Ca}(\mathrm{OH})_{2}$ is a beneficial additive to the $\mathrm{Zn}$ electrode in $\mathrm{Zn} / \mathrm{AgO}$ cells, it is suggested that further research focus on investigations of $\mathrm{ZnCa} / \mathrm{AgO}$ cells to better understand the mechanism whereby the capacity improvements are realized, the development of $\mathrm{ZnCa} / \mathrm{AgO}$ cells with improved wetting characteristics, the fabrication of sealed $\mathrm{ZnCa} / \mathrm{AgO}$ cells, and characterization of large $\mathrm{ZnCa} / \mathrm{AgO}$ cells. 


\section{ACKNOWLEDGMENTS}

BST, Inc. provided several $\mathrm{Zn} / \mathrm{AgO}$ cells, electrodes and cell pars. These materials were indispensable for the initiation of our experimental program, and for providing comparisons to LBL-fabricated cells. The authors wish to thank BST for providing these useful materials. The experimental and analytic help provided by Mr. Thomas Adler and Dr. Kathryn Striebel is gratefully acknowledged.

This work was supported by the Defense Advanced Research Projects Agency, Undersea Warfare Office, Submarine Technology Program, under ARPA Order Number MIPR N0002490MP70004, through the U.S. Department of Energy under Contract No. DE-AC0176SF00098.

\section{REFERENCES}

1. D. Linden, in Handbook of Batteries \& Fuel Cells, McGraw-Hill, Inc., New York, 1984.

2. A. Himy, in Silver-Zinc Battery - Phenomena and Design Principles, Vantage Press, New York. 1986.

3. F.R. McLarnon and E.J. Cairns, J. Electrochem. Soc., 138, 645 (1991).

4. E.G. Gagnon, J. Electrochem. Soc., 133, 1989 (1986).

5. R. Jain, F.R. McLarnon and E.J. Cairns, Lawrence Berkeley Laboratory Report No. LBL. 25332, (1989).

6. E.G. Gagnon and R.A. Sharma, J. Electrochem. Soc., 133, 2215 (1986)

7. J.T. Nichols, F.R. McLarnon and E.J. Cairns, Lawrence Berkeley Laboratory Report No. 17397 (1983).

8. M.H. Katz, J.T. Nichols, F.R. McLamon, and E.J. Cairrs, J. Power Sources, 10, 149 (1983).

9. D.A. Skoog, D.M. West and F.J. Holler, in Fundamentals of Analytical Chemistry, Saunders College Publishing, (1988).

10. Y.-M. Wang, J. Electrochem. Soc., 137, 2800 (1990).

11. T.P. Dirkse, J. Electrochem. Soc., 106, 453 (1959).

12. A. Fleicher and J.J. Lander (eds.), in Zinc-Silver Oxide Batteries, p.136, John Wiley \& Sons, Inc., 1971. 


\section{APPENDIX : Design Calculations for the $\mathrm{Zn} / \mathrm{AgO}$ Cell}

Desired Capacity $=5 \mathrm{Ah}$

Cycle Life : > 40 cycles @ 100\% DOD

Discharge Rate $=C / 5=1 \mathrm{Amp}$

Electrode Size : $1.75^{\prime \prime} \times 1.4^{\prime \prime}(4.4 \mathrm{~cm} \times 3.6 \mathrm{~cm})$

Cycling Methode $=\mathrm{CC}$

Cell Pack $=6$ plates of positive electrodes and 7 plates of negative electrodes; outside plates are negative $(-/$ sep. $/+/$ sep. $/-/$ sep. $/+/$ sep. $/-/ \ldots)$

\section{$* * * * * * * * * * * * * * * * * \quad$ Calculations}

Practical utilization of $\mathrm{Ag}=3 \mathrm{~g} / \mathrm{Ah}$ ( $1.3 \times$ theoretical)

Total mass of $\mathrm{Ag}=\mathrm{Mag}=3(\mathrm{~g} / \mathrm{Ah}) \times 5(\mathrm{Ah})=15 \mathrm{~g}-\mathrm{Ag}$

Let $: \mathrm{K}=\mathrm{Mzn} / \mathrm{Mag}=1.15$ (cycle life $(>40$ cycles) required)

Total mass of $\mathrm{Zn}=\mathrm{Mzn}=15(\mathrm{~g}) \times 1.15=17.25 \mathrm{~g}-\mathrm{Zn}(2.83 \times$ theoretical $)$

$\mathrm{Ag}$ loading for each $\mathrm{Ag}$ plate $=\mathrm{Mag} / 6=2.5 \mathrm{~g}-\mathrm{Ag}$

$\mathrm{Zn}$ loading for erch $\mathrm{Zn}$ plate $=\mathrm{Mzn} / 6=2.87 \mathrm{~g}-\mathrm{Zn}$

Assume equivalent thickness of current collector $=1 \mathrm{mil}$

Let : $\mathrm{dag}=4.5\left(\mathrm{~g}-\mathrm{Ag} / \mathrm{cm}^{3}\right)$ and $\mathrm{dzn}=1.54\left(\mathrm{~g}-\mathrm{Zn} / \mathrm{cm}^{3}\right)$

$\mathrm{P}=$ thickness of $\mathrm{Ag}$ plate

$\mathrm{N}=$ thickness of Zit plate

$2.5(\mathrm{~g}-\mathrm{Ag} /$ plate $)=15.8\left(\mathrm{~cm}^{2} /\right.$ plate $) \times(\mathrm{P}-0.00254)(\mathrm{cm}) \times 4.5\left(\mathrm{~g}-\mathrm{Ag} / \mathrm{cm}^{3}\right)$

$2.87(\mathrm{~g}-\mathrm{Zn} /$ plate $)=15.8\left(\mathrm{~cm}^{2} /\right.$ plate $) \times(P-0.00254)(\mathrm{cm}) \times 1.54\left(\mathrm{~g}-\mathrm{Zn} / \mathrm{cm}^{3}\right)$

Then, $P=0.0377 \mathrm{~cm}=15$ mils;

$\mathrm{N}=0.1207 \mathrm{~cm}=48 \mathrm{mils}$ 


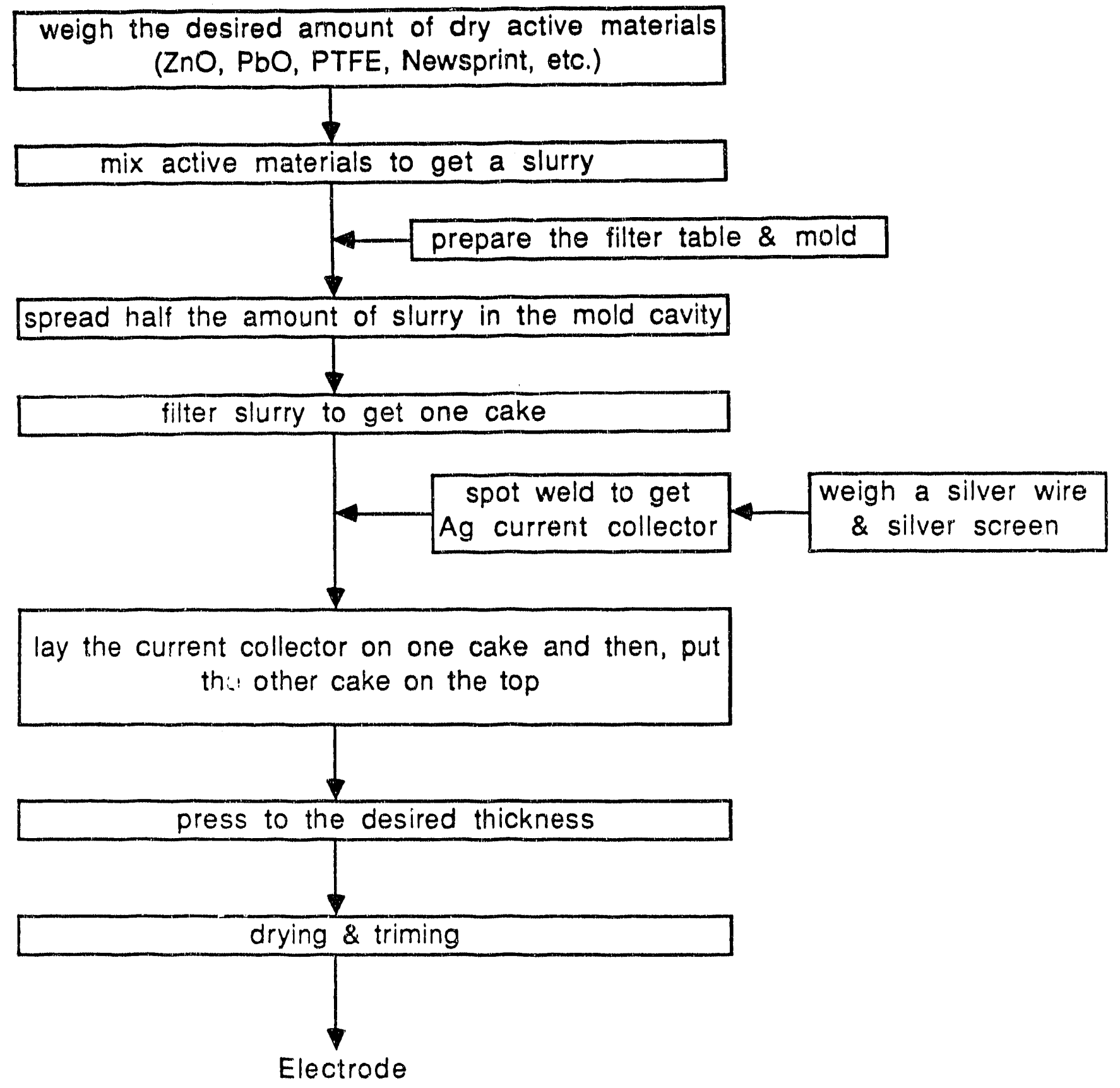

Figure 1 : Flow Chart for Making Zinc Electrodes for $\mathrm{Zn} / \mathrm{AgO}$ Cells 


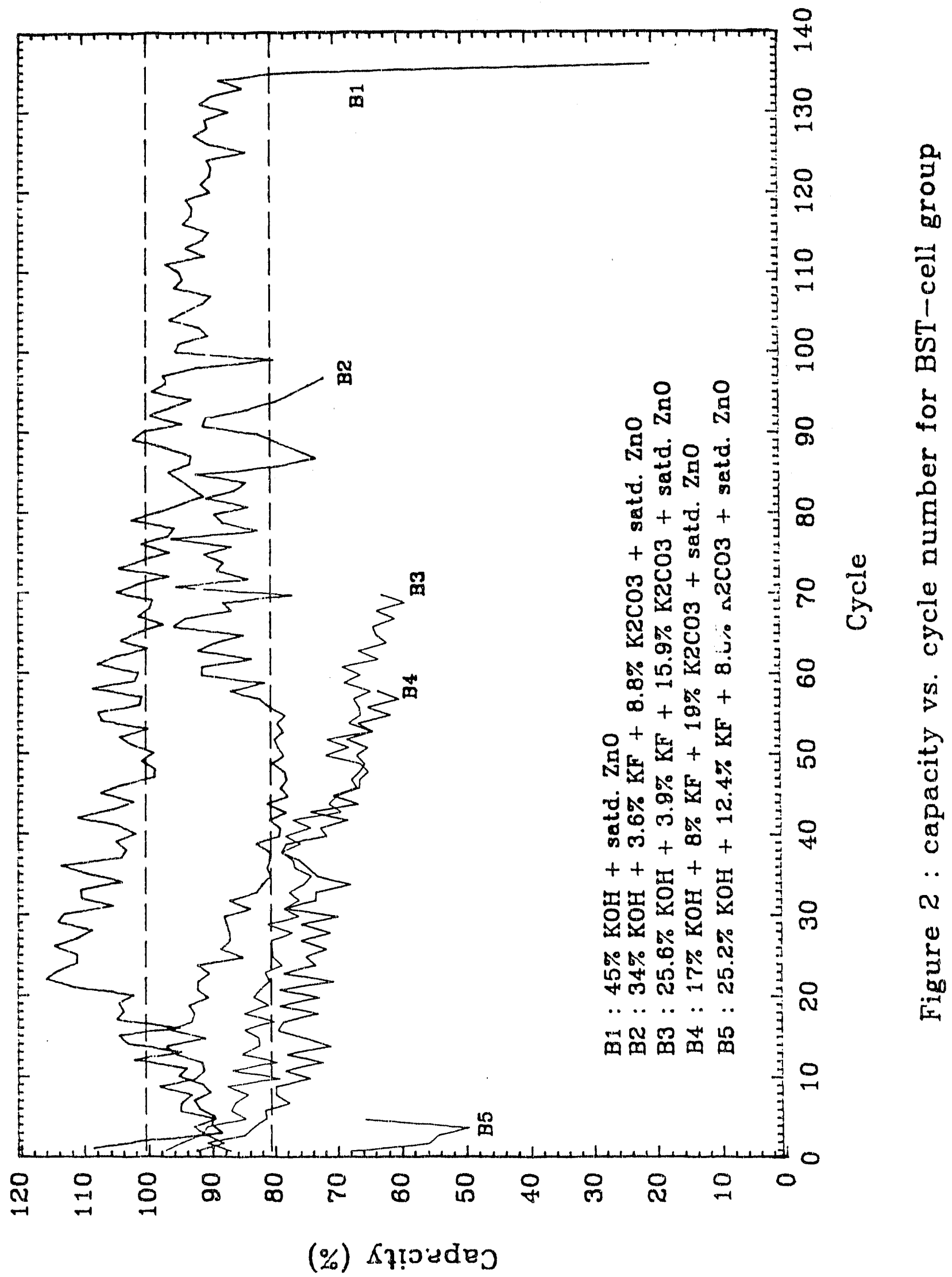




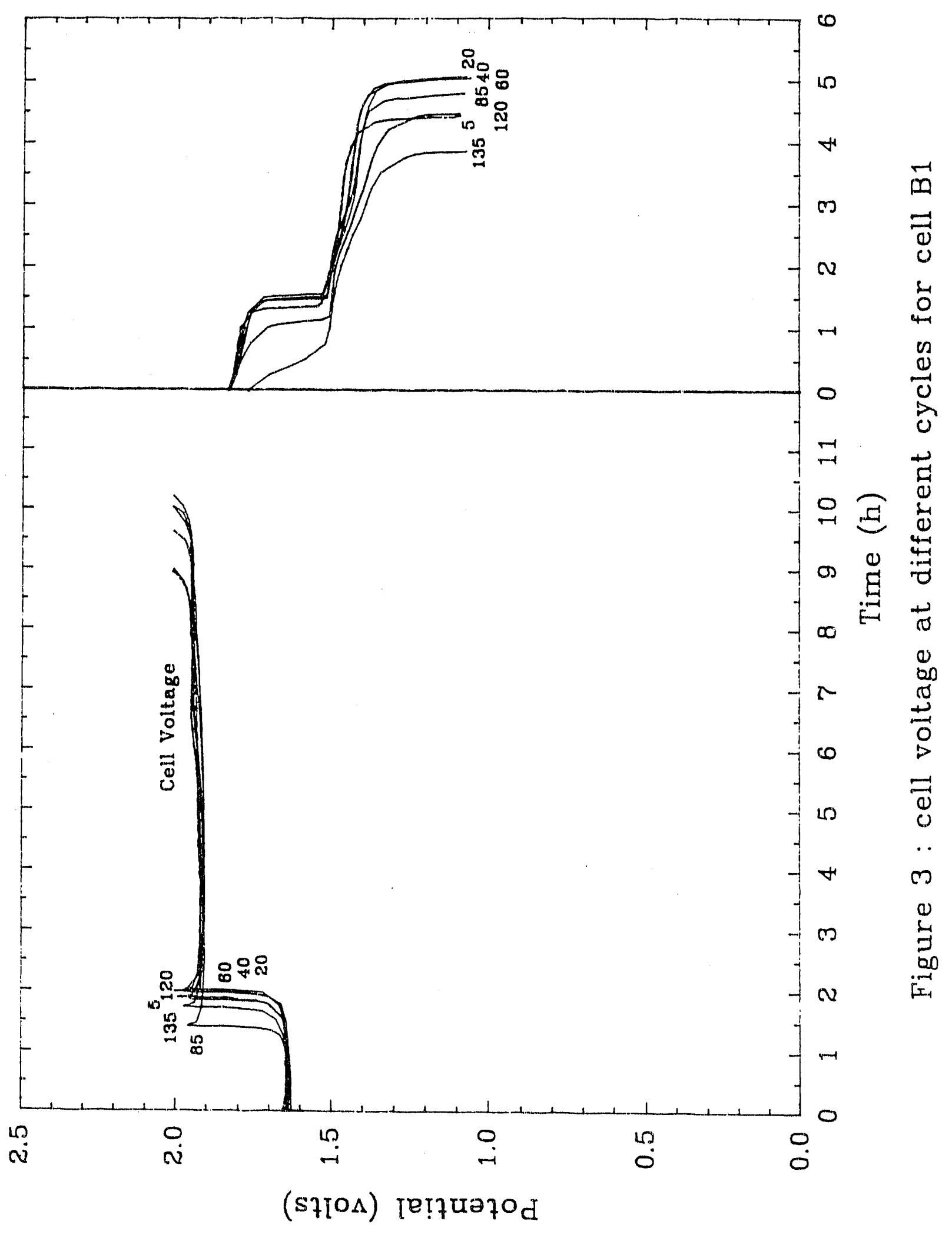




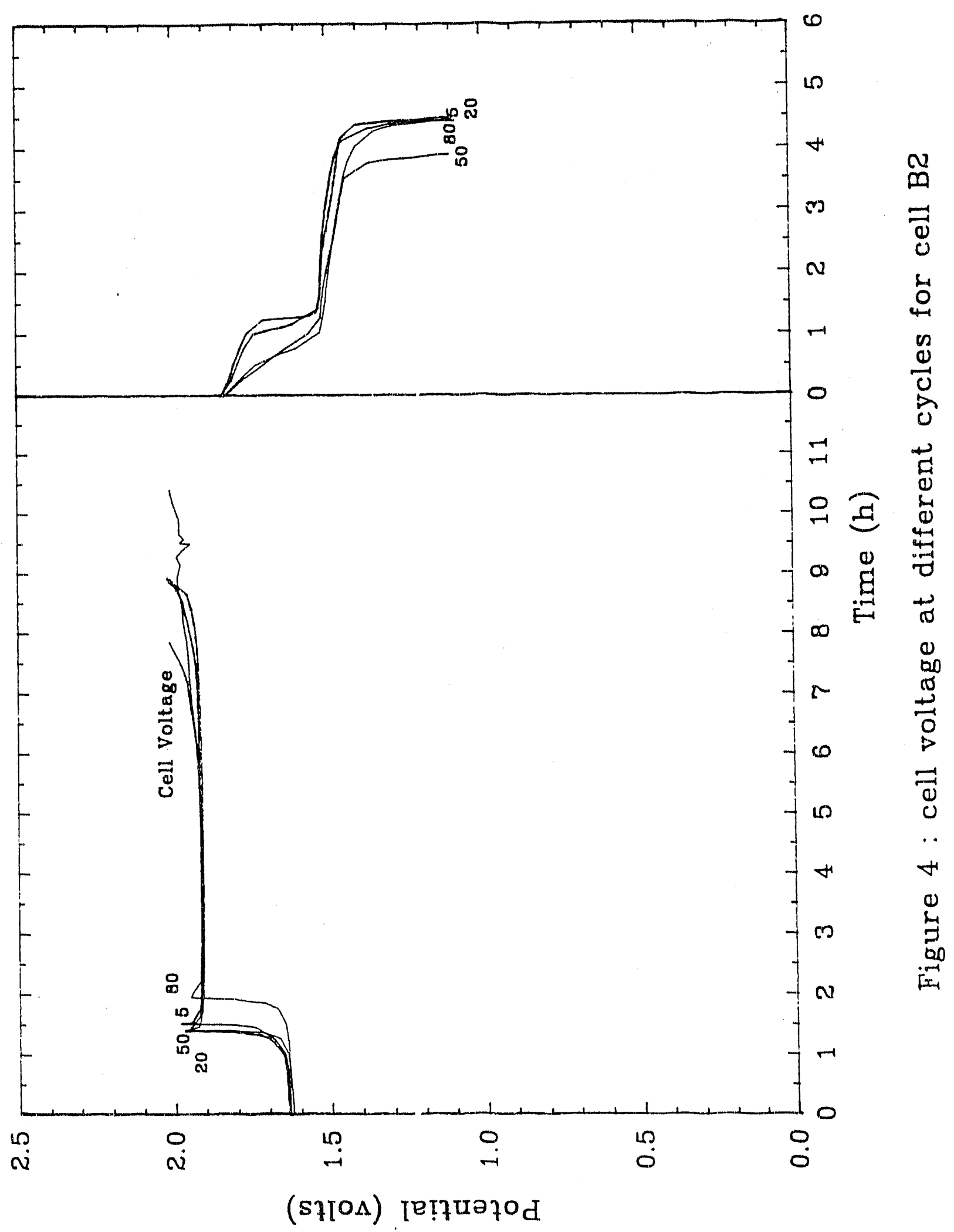




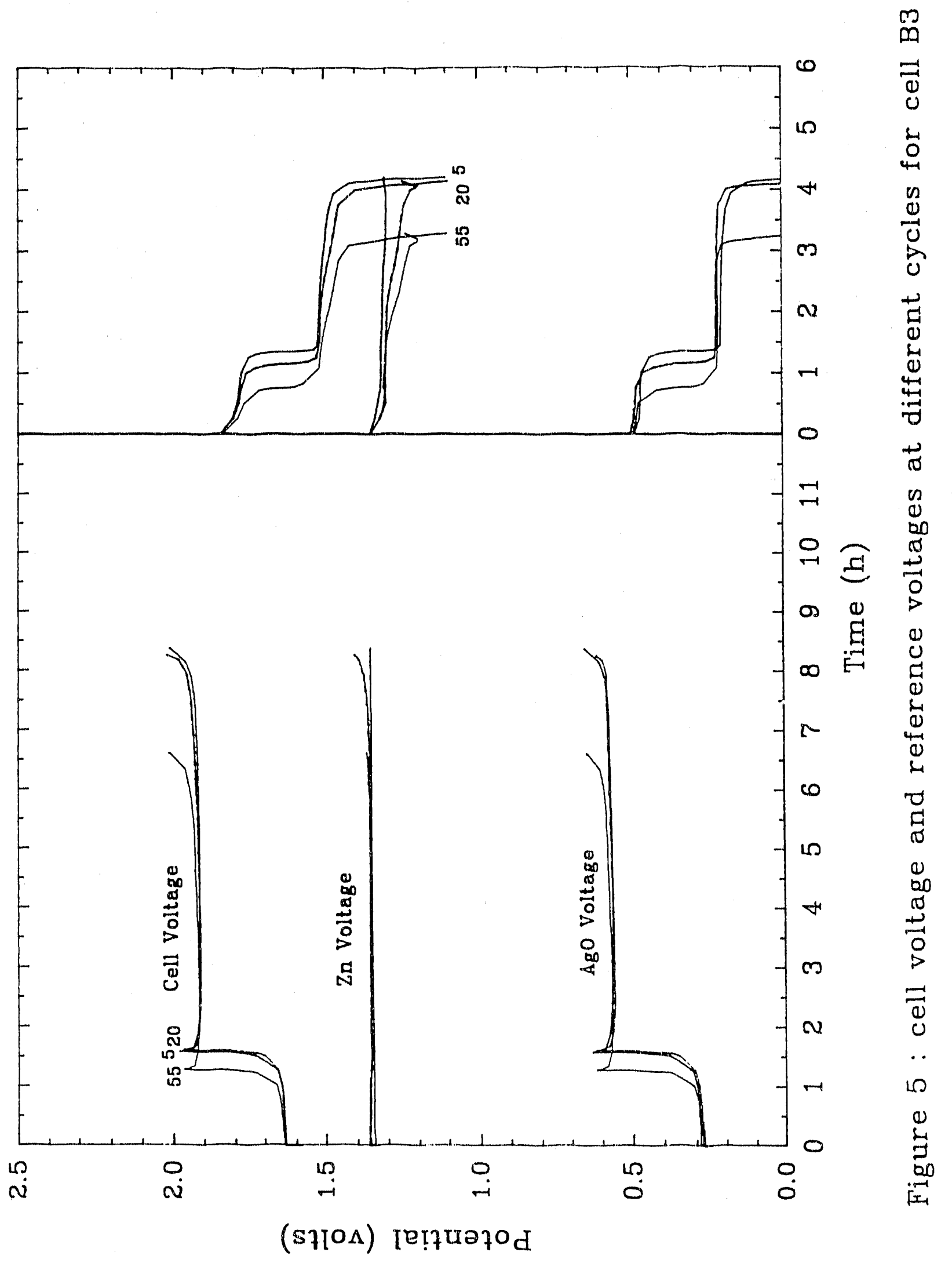




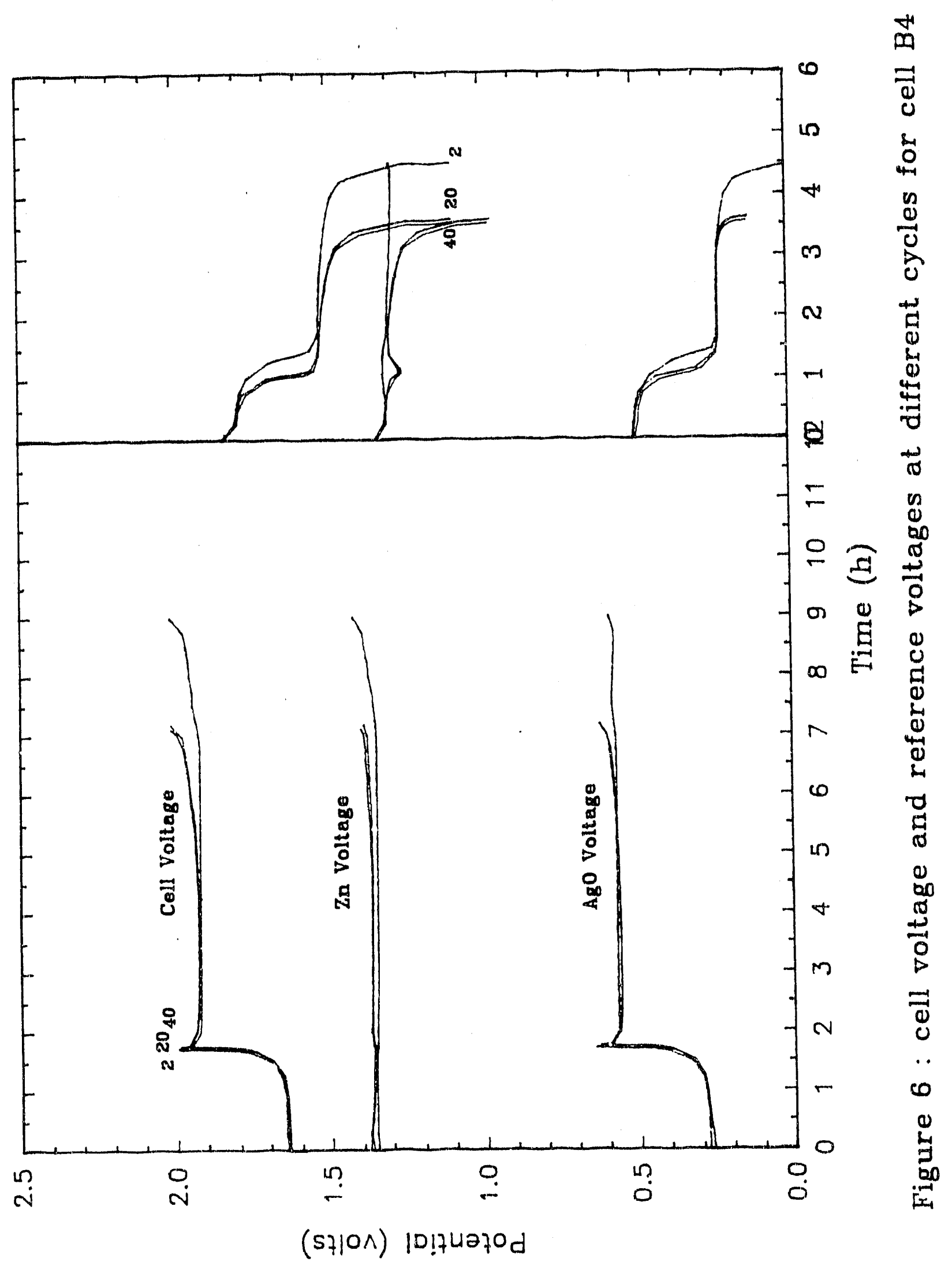




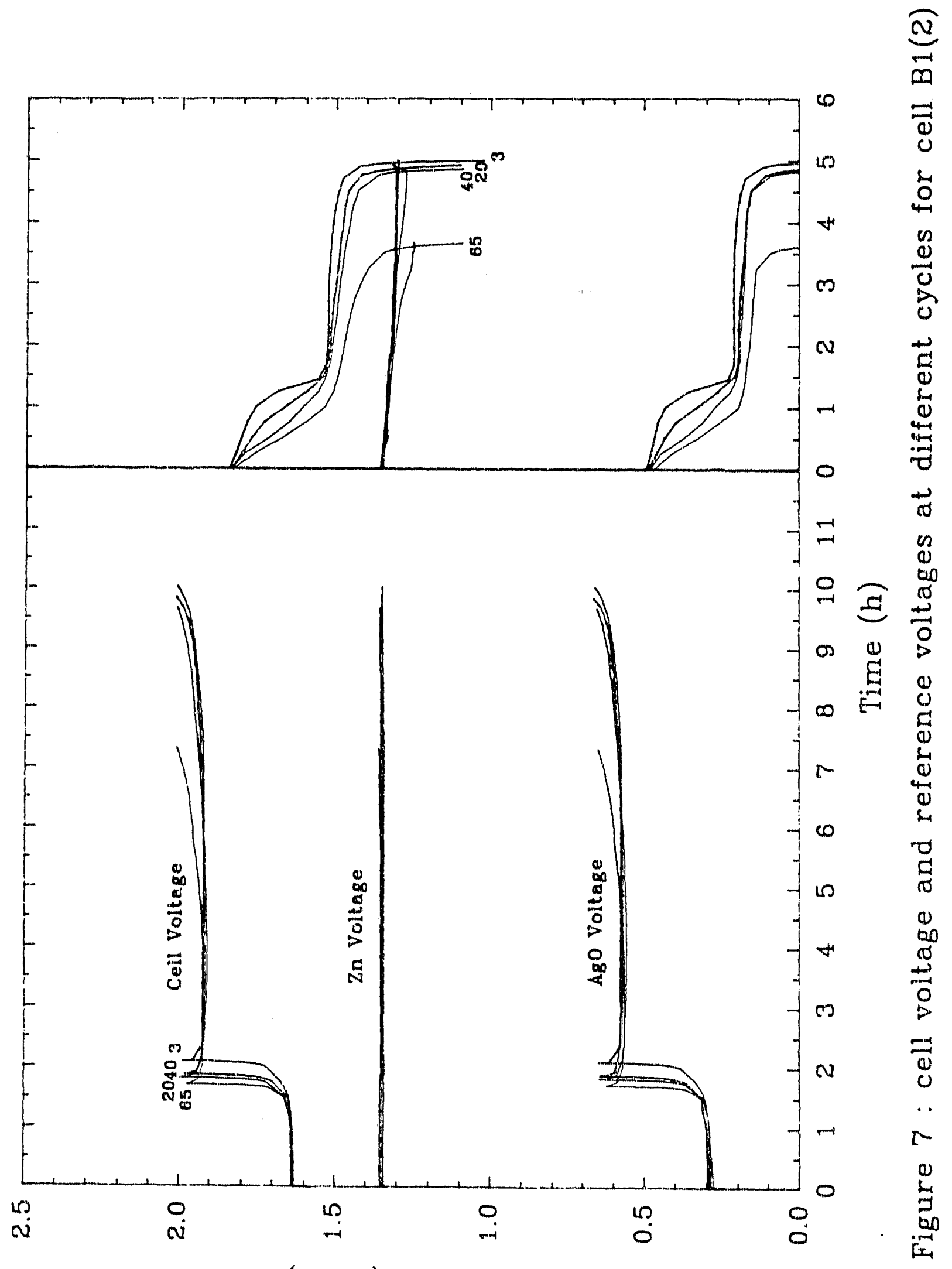

(s7101) Iет74ว70d 


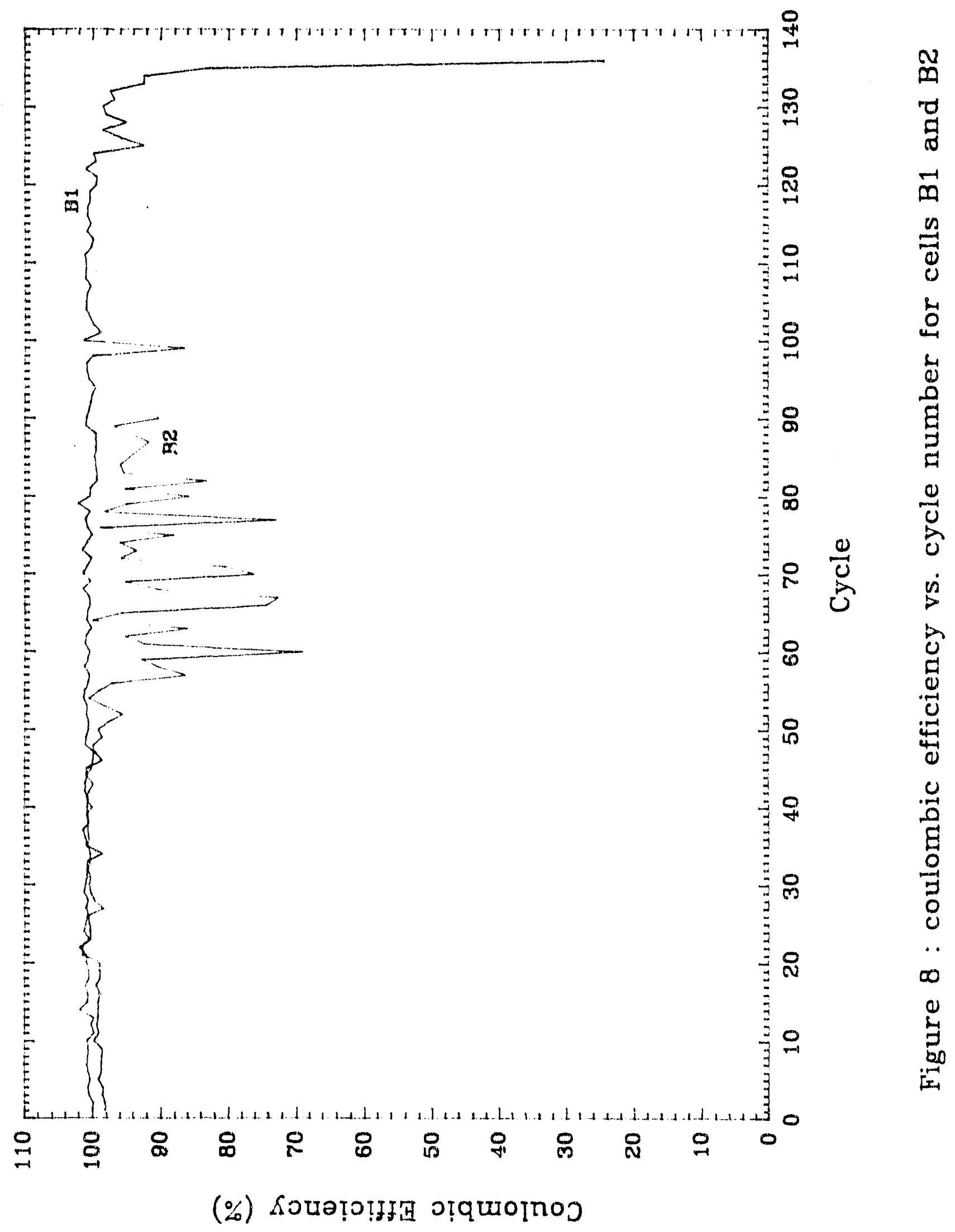




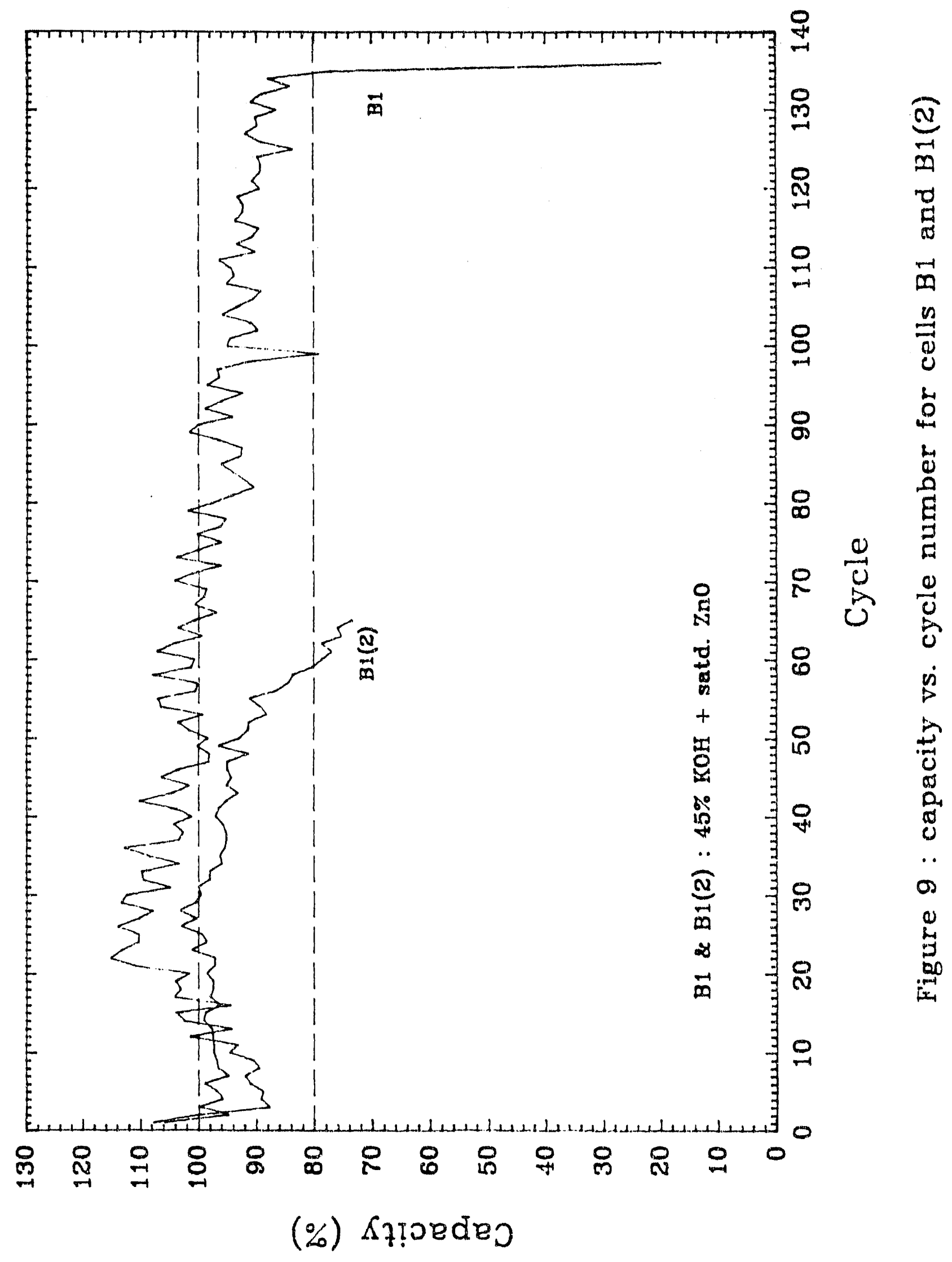




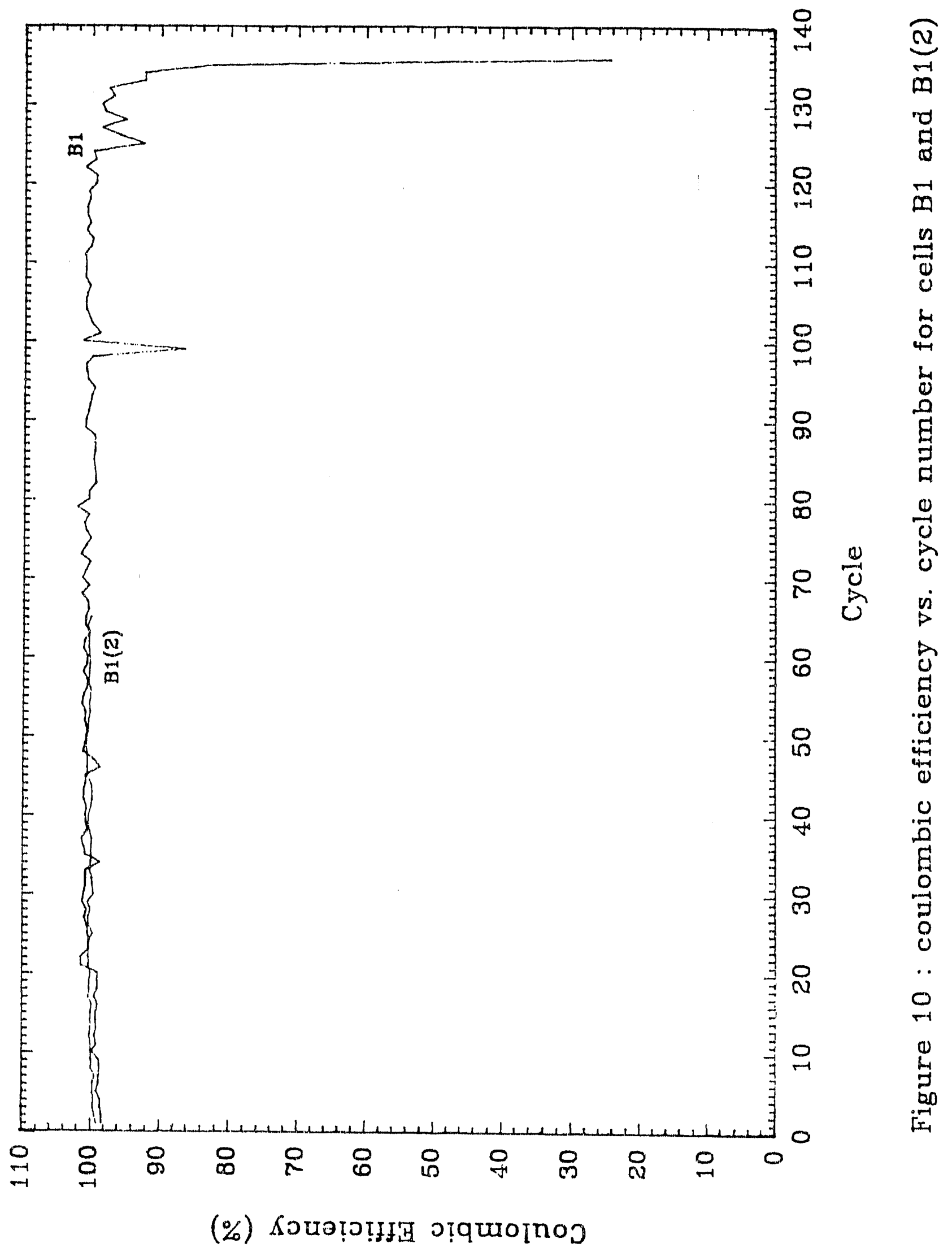




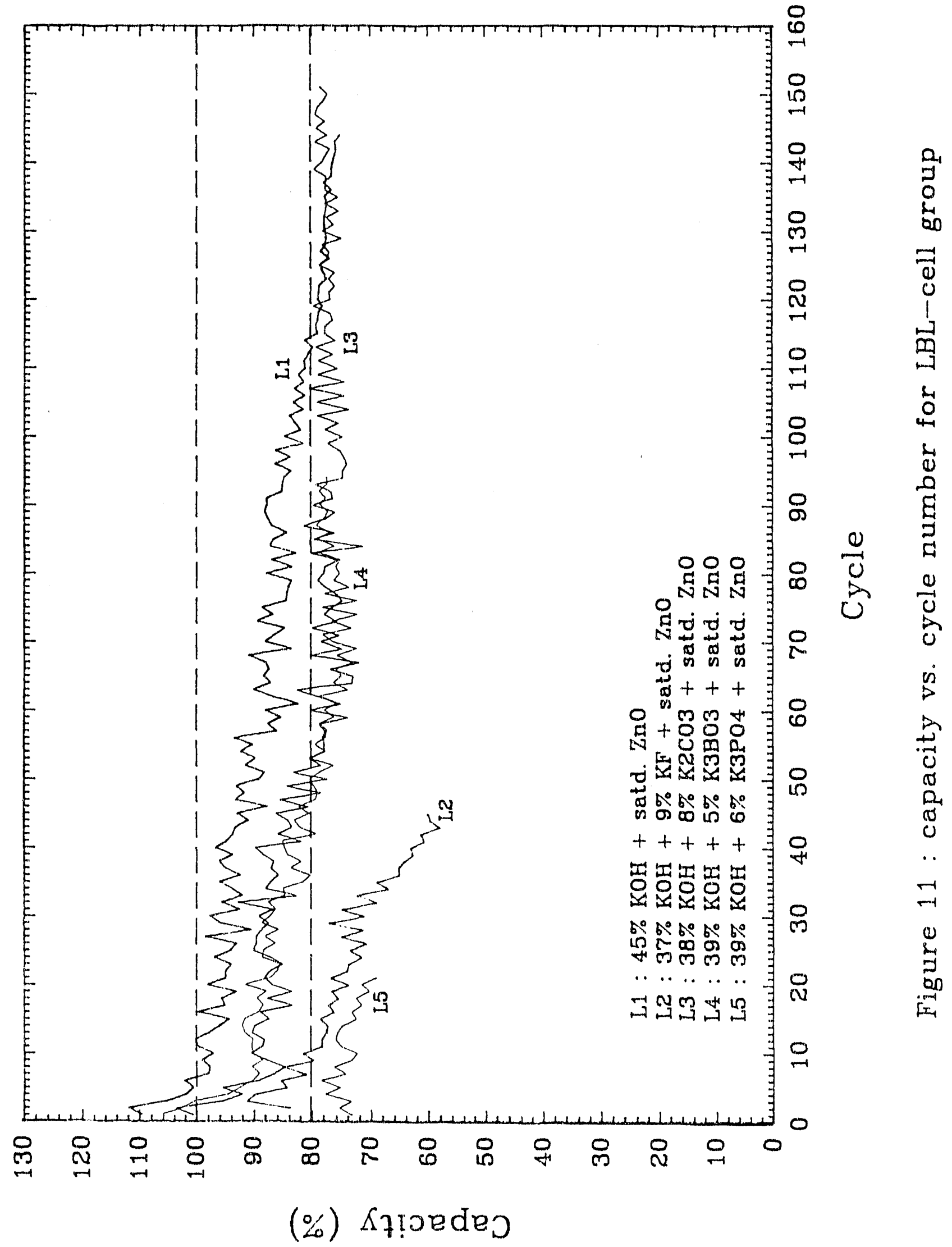




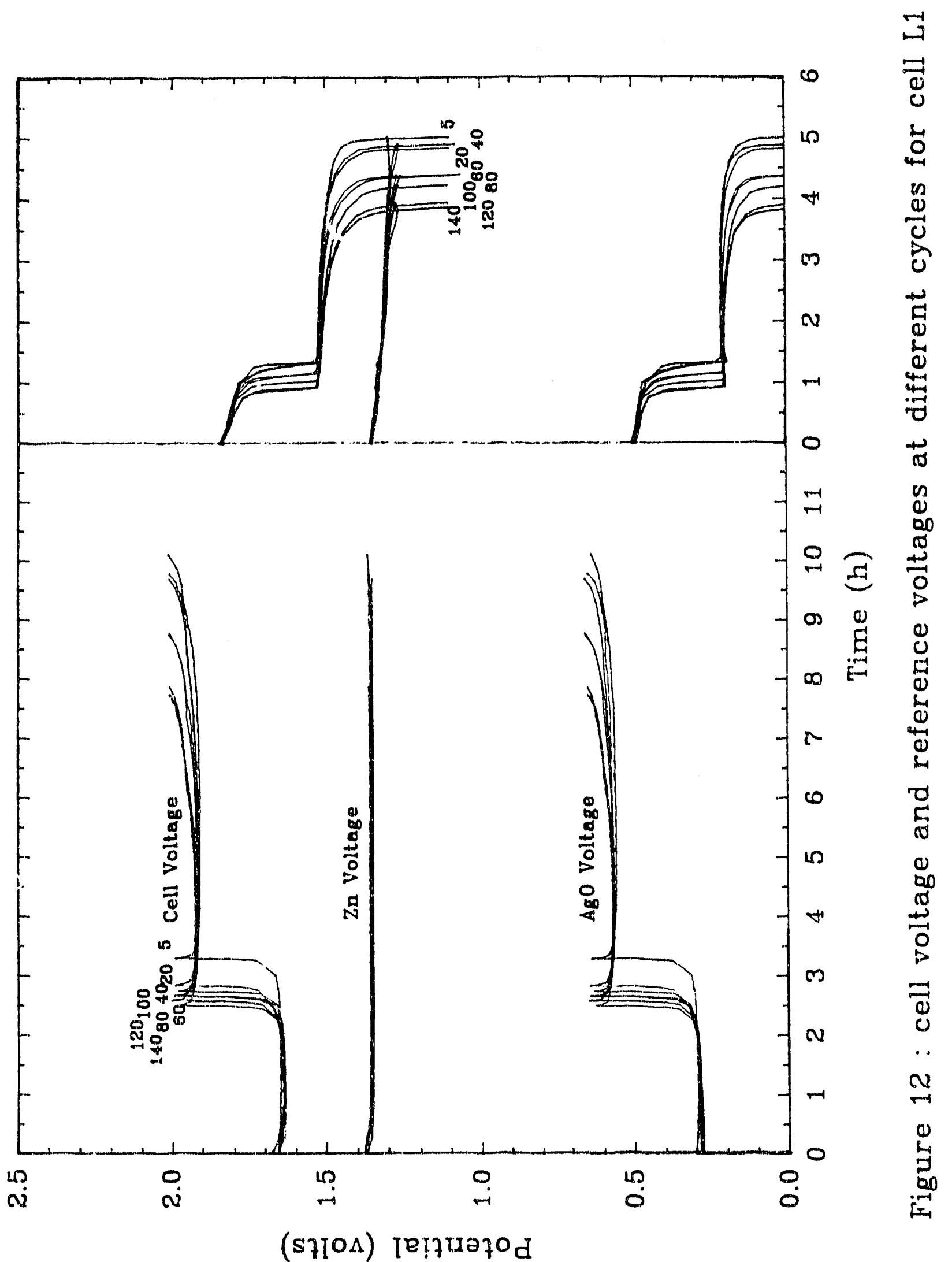




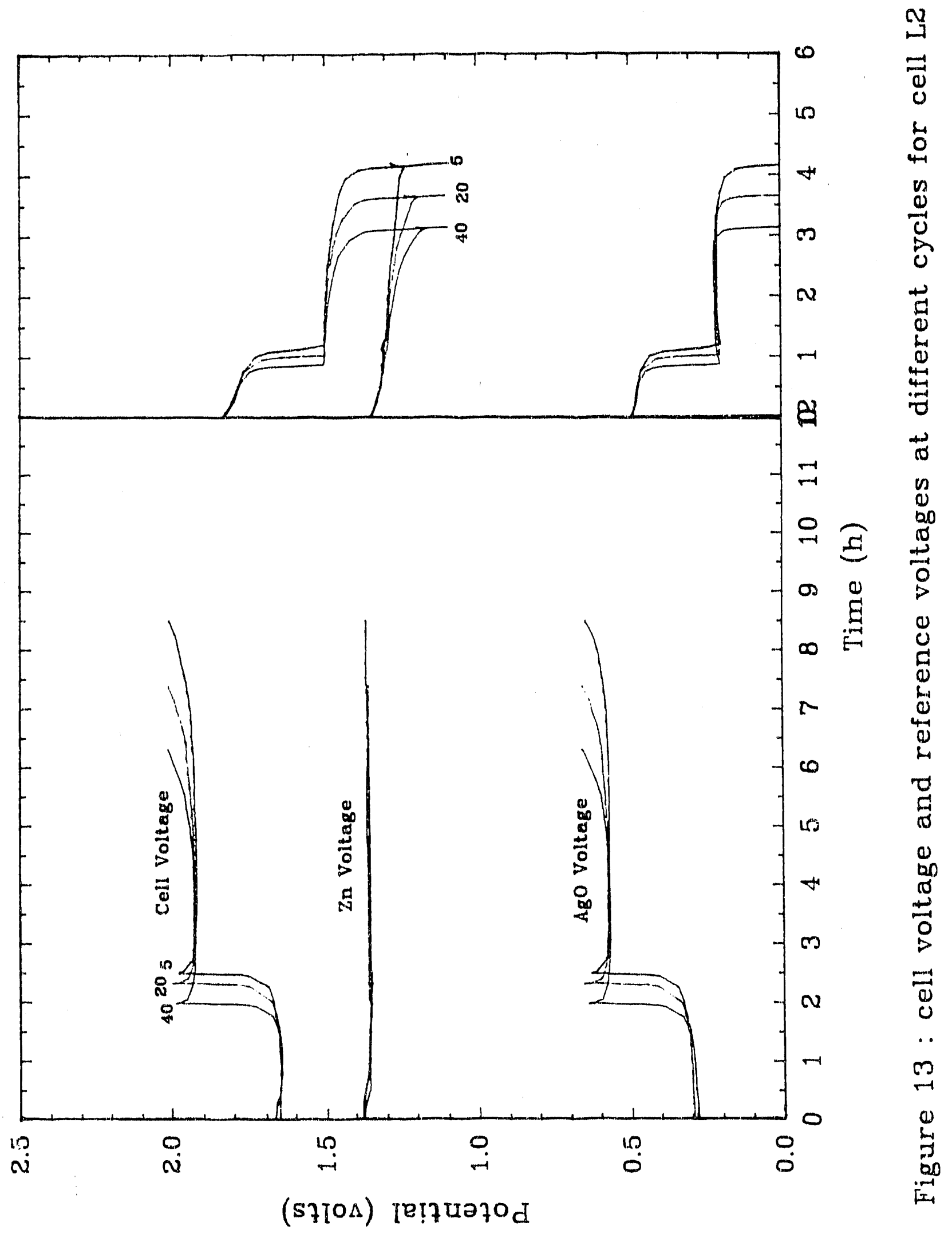




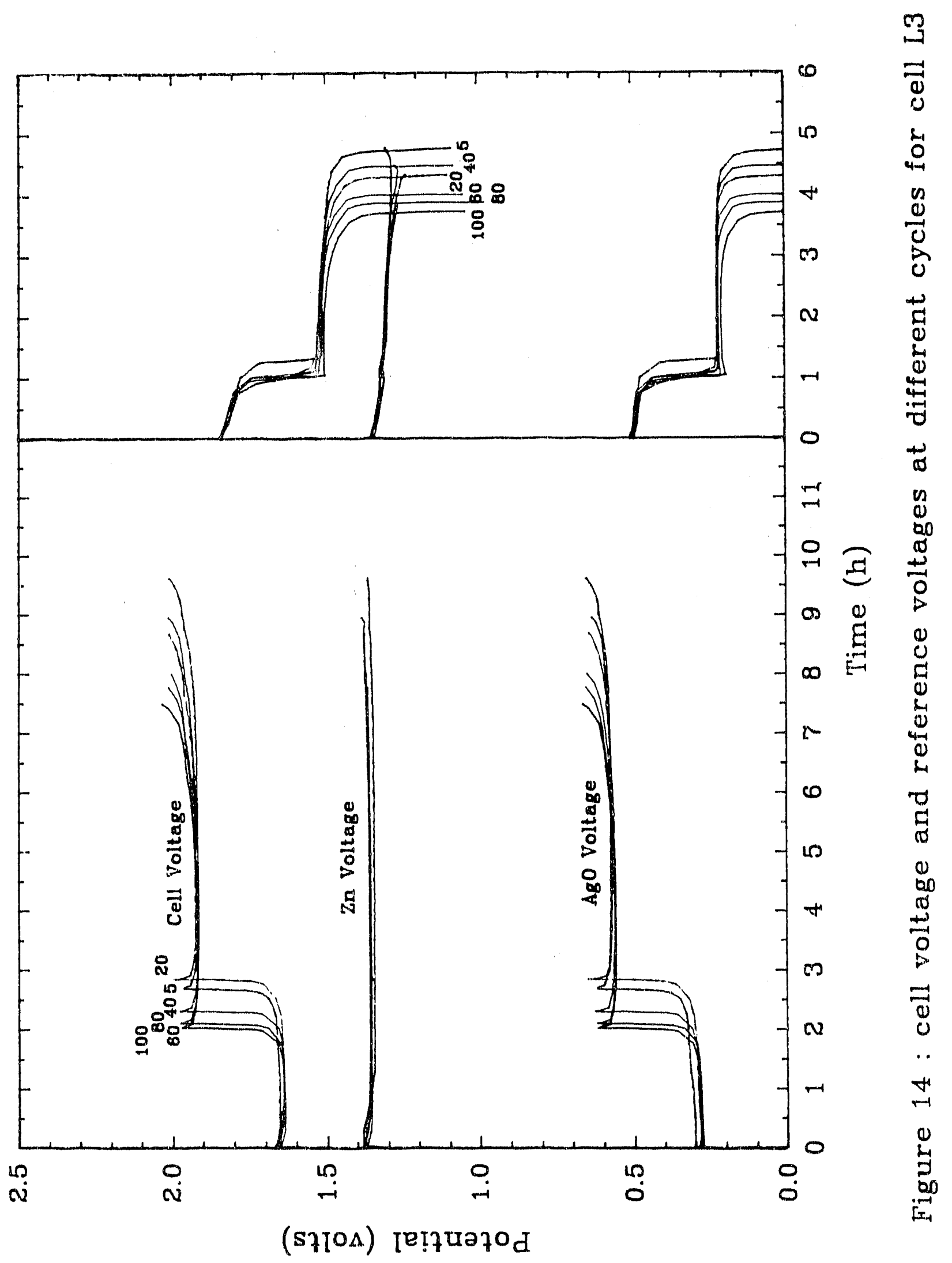




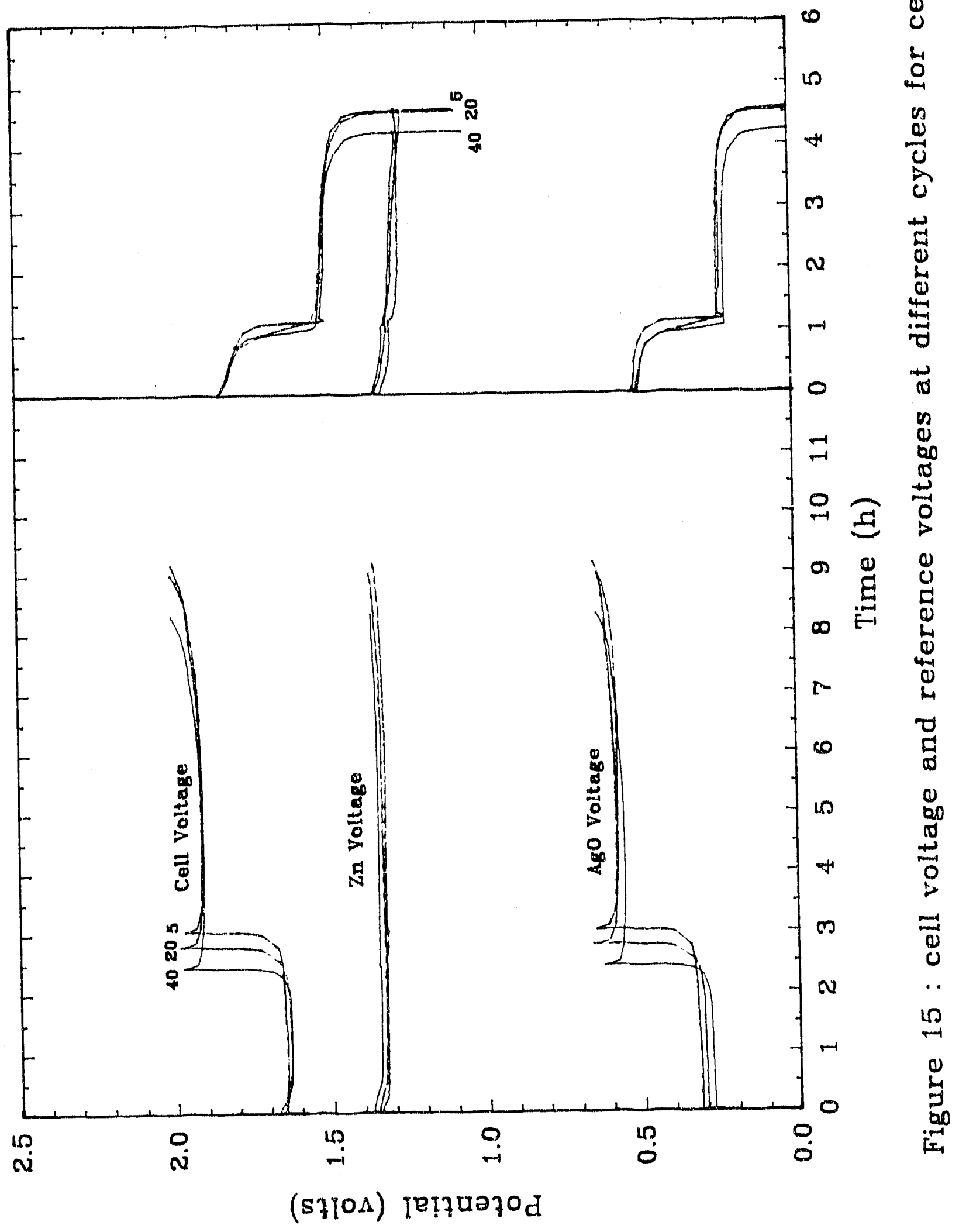




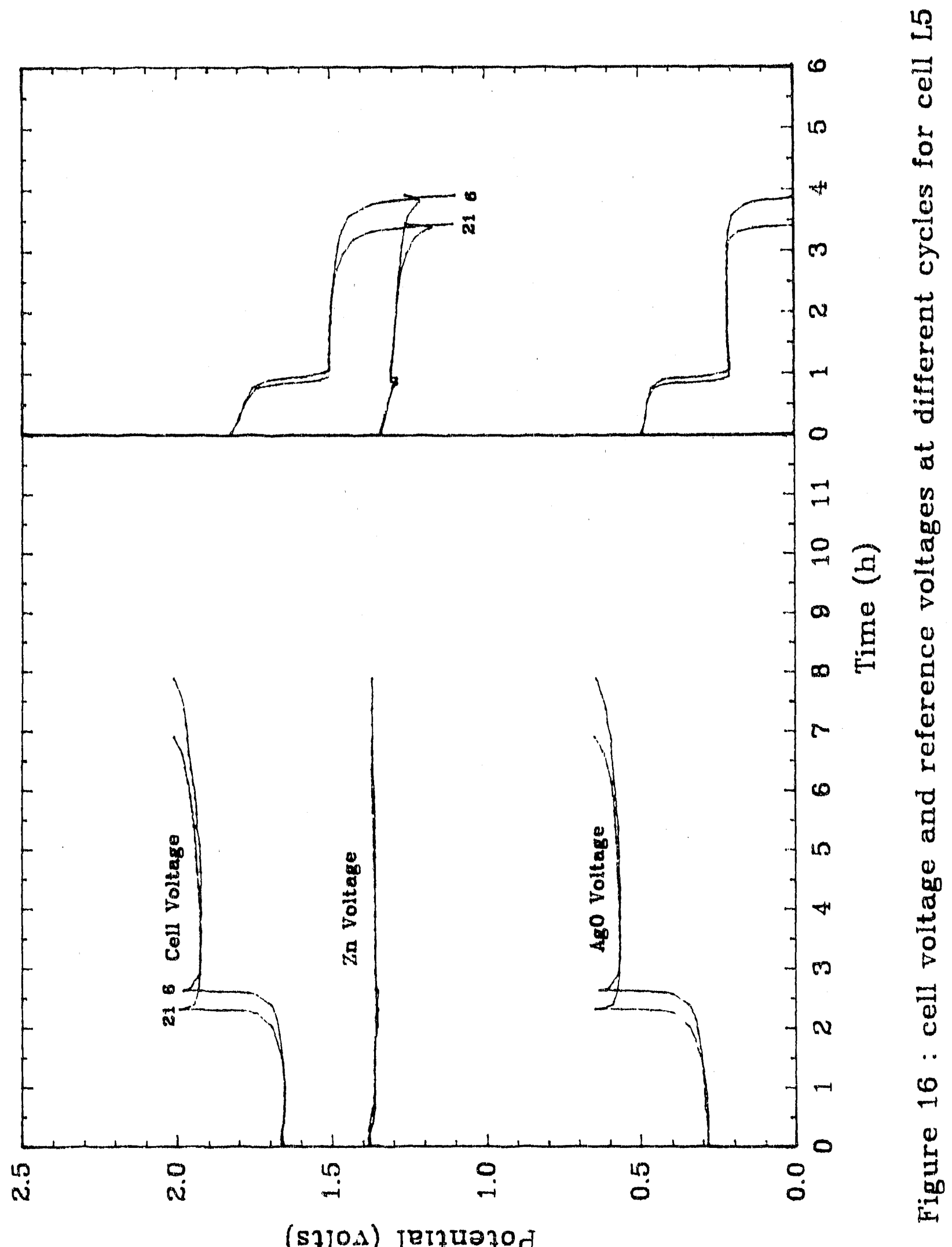




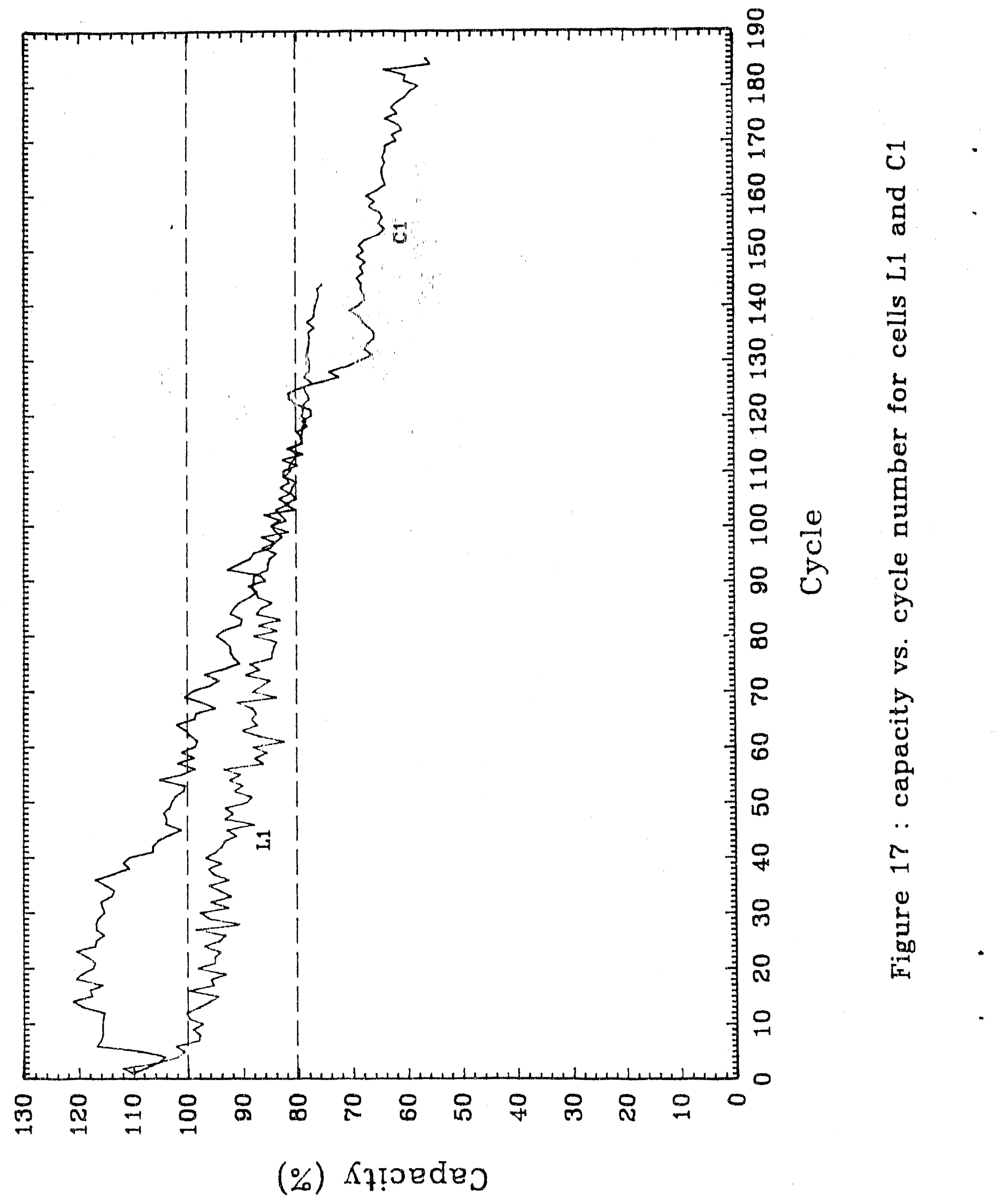




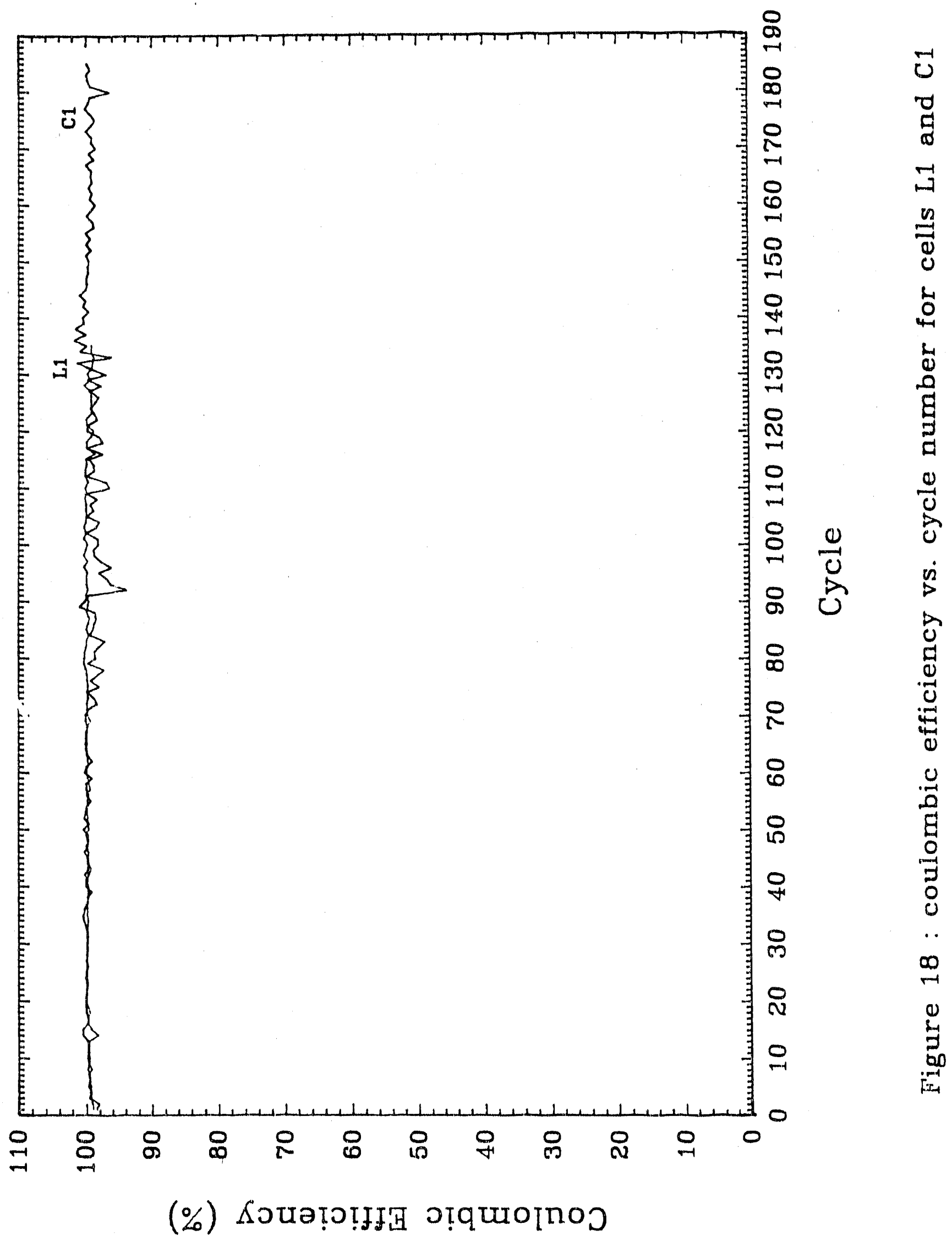




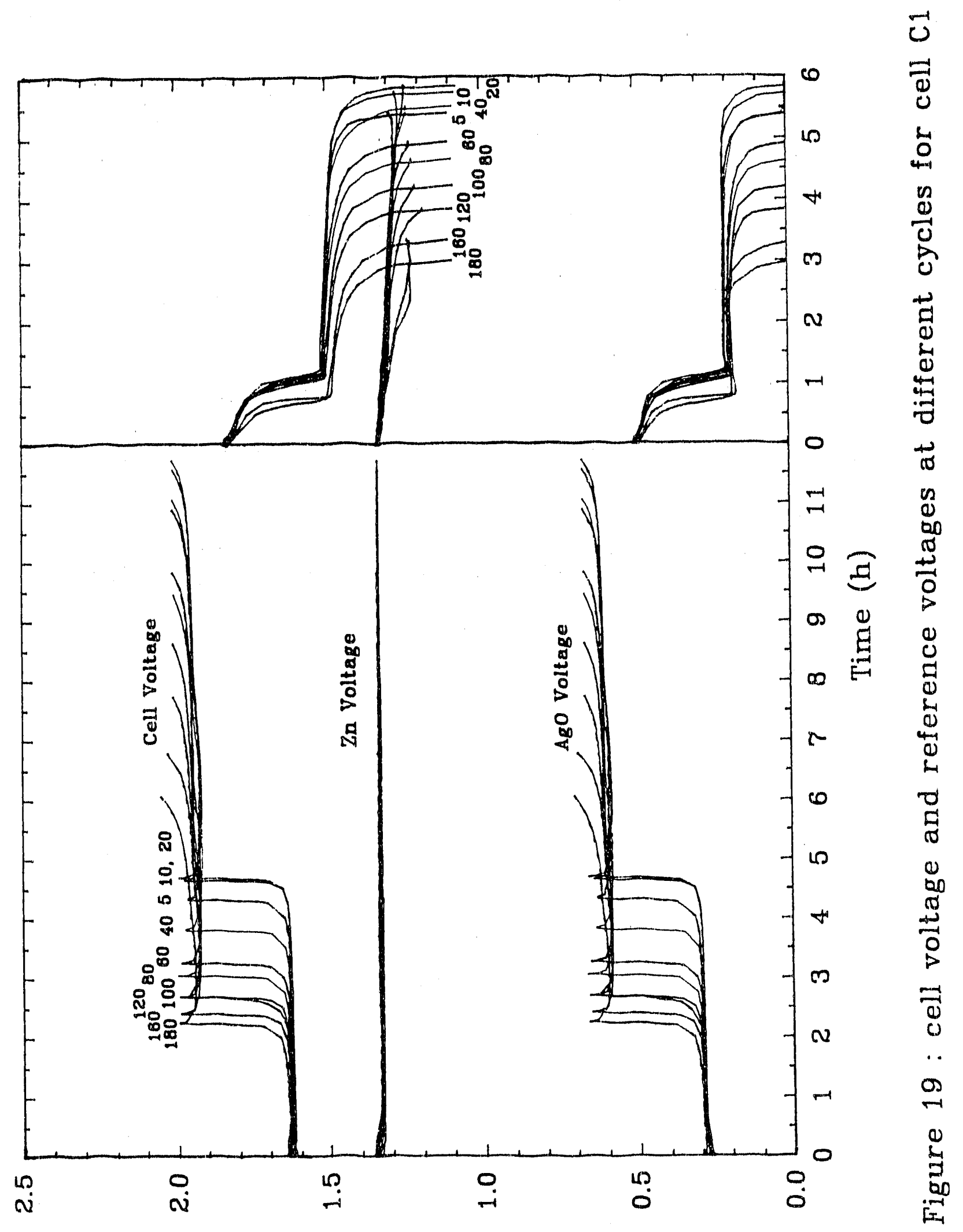

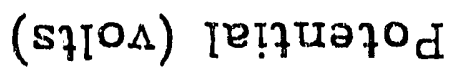




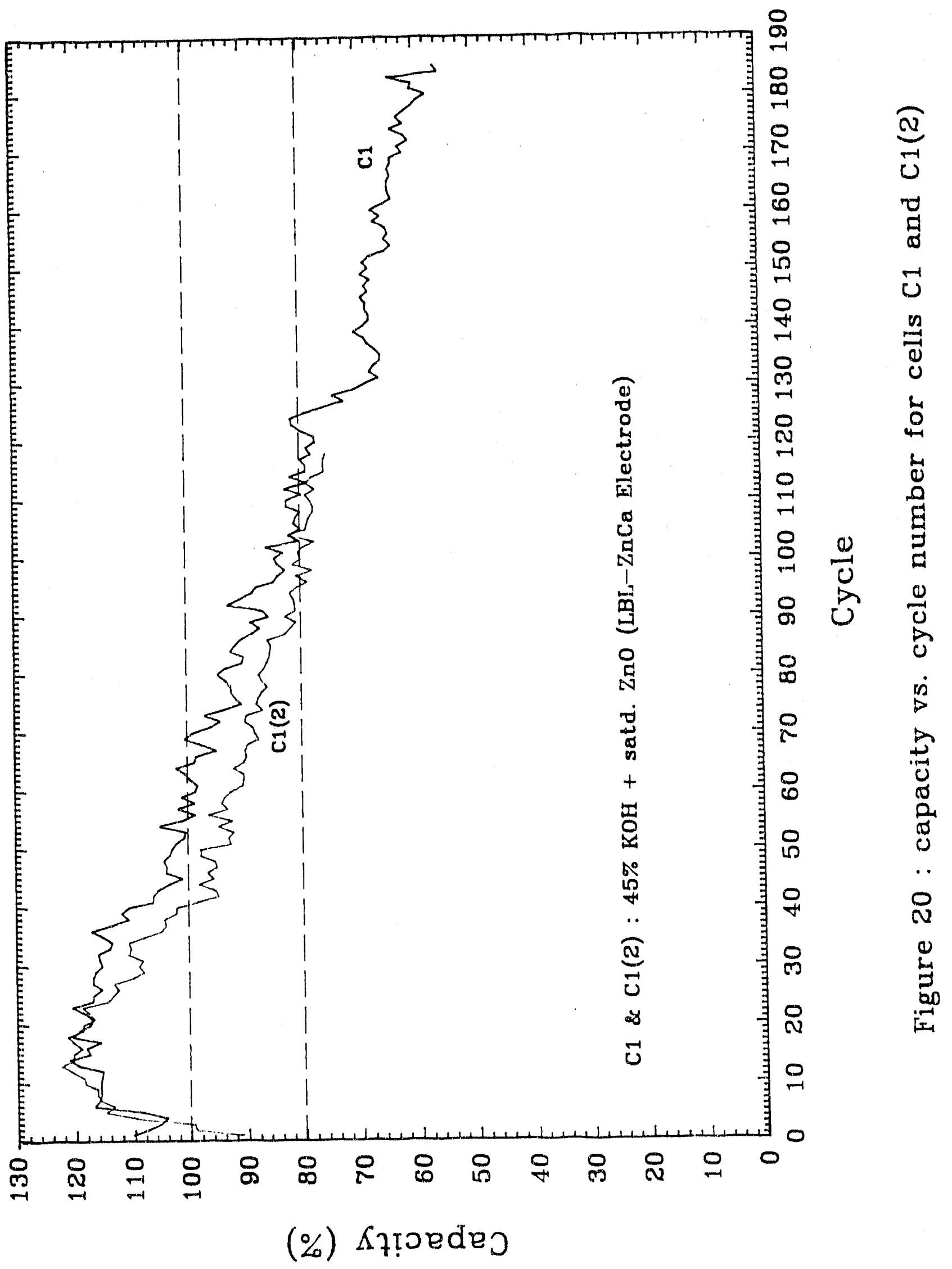




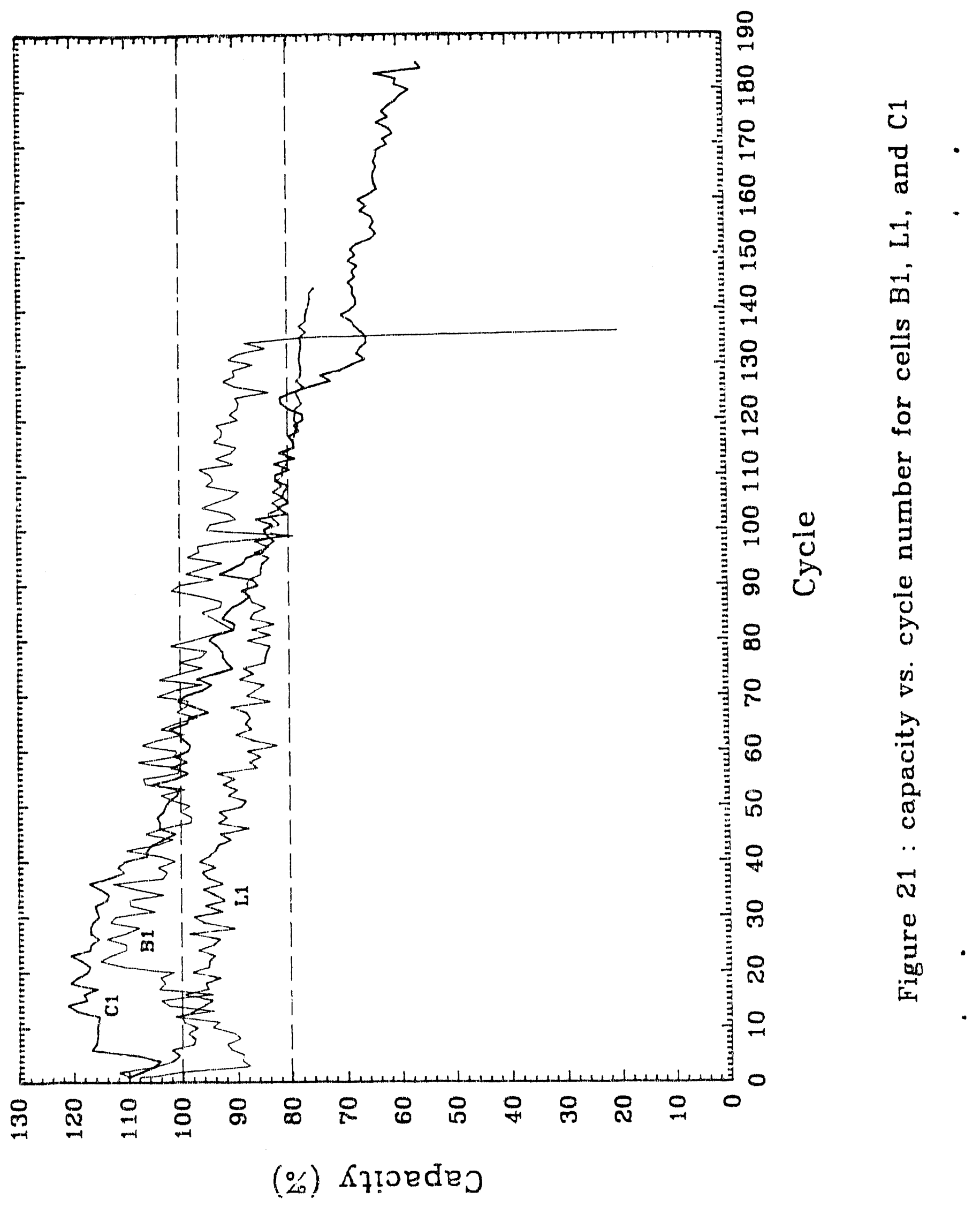




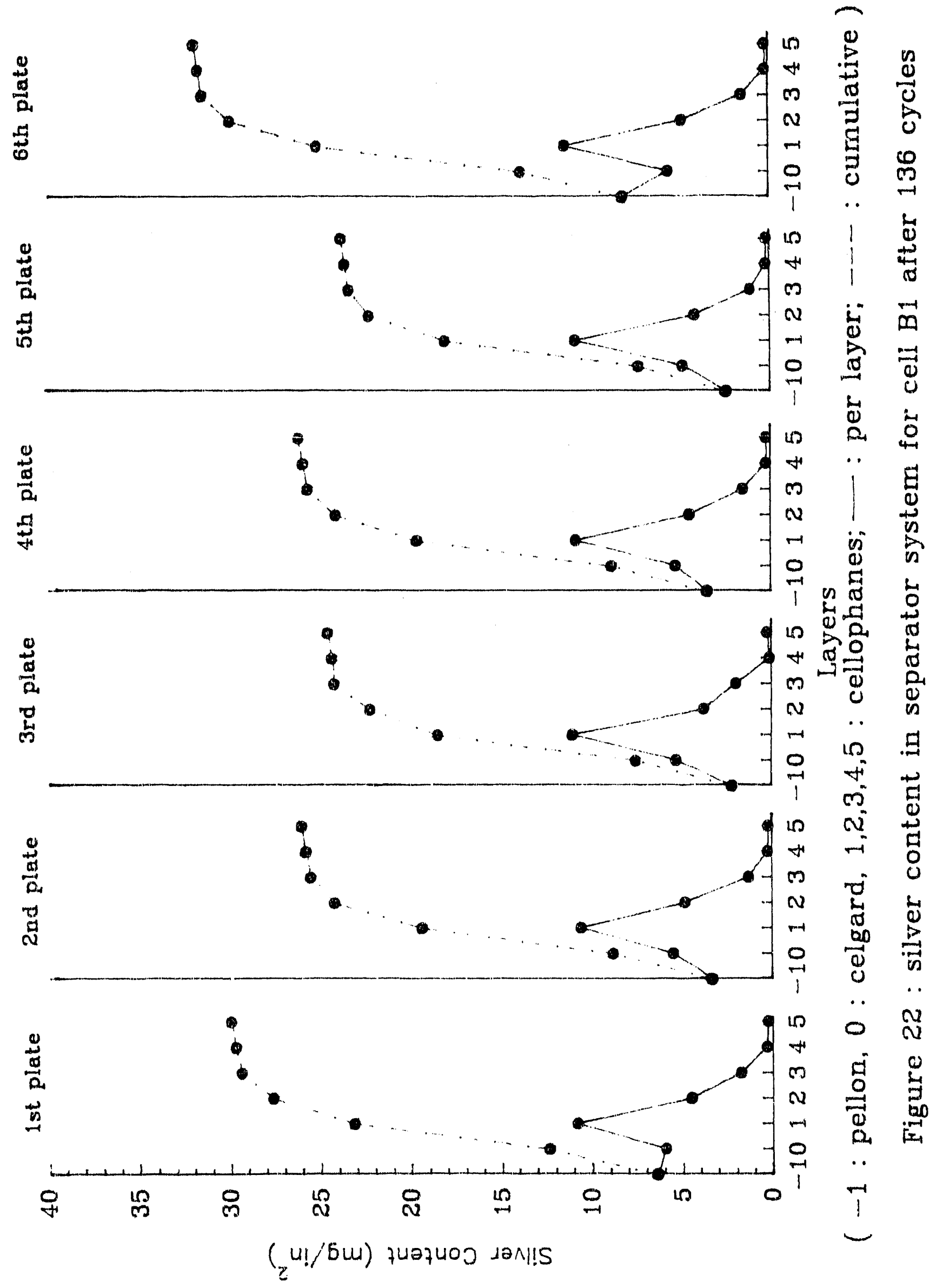



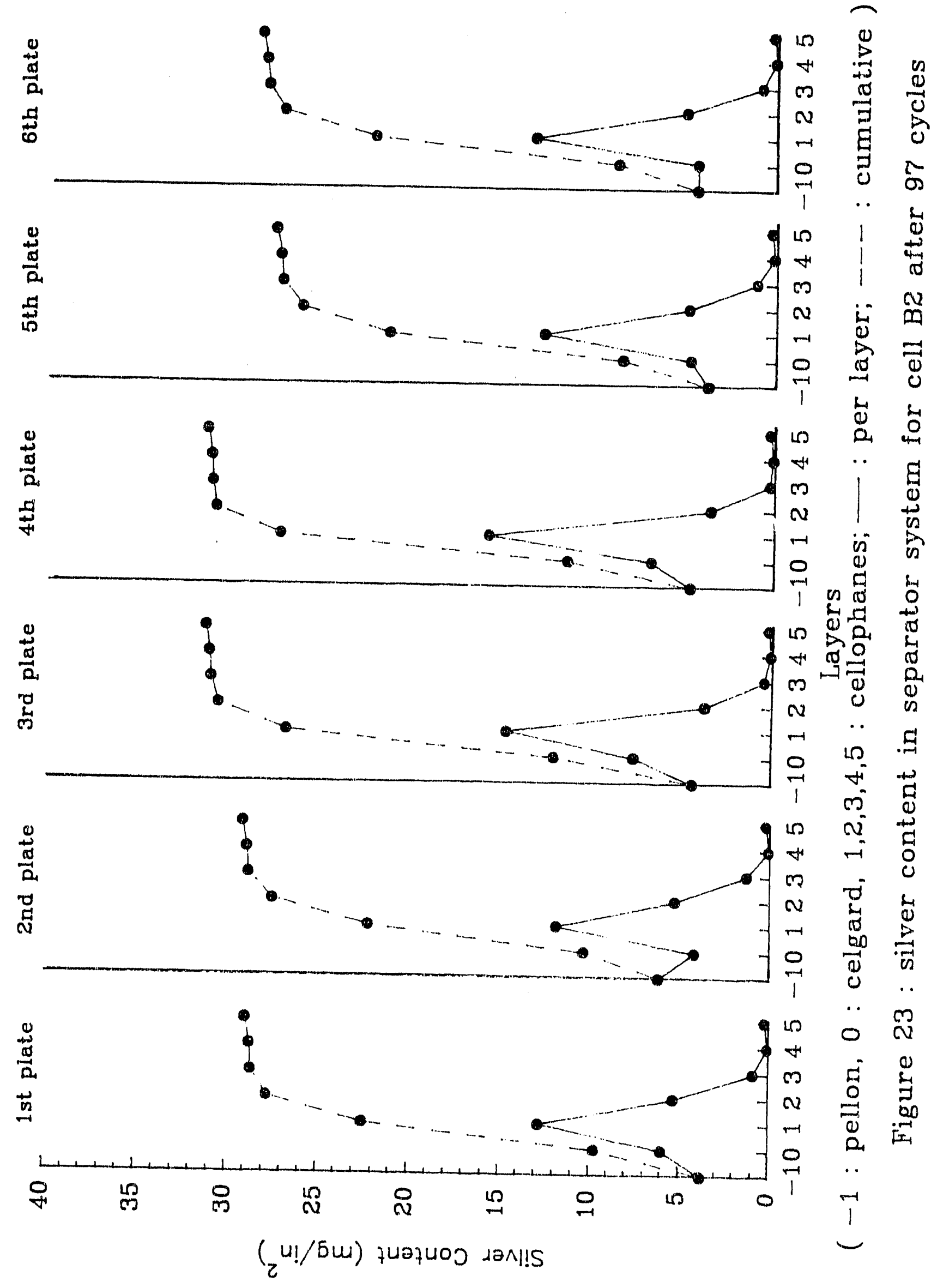


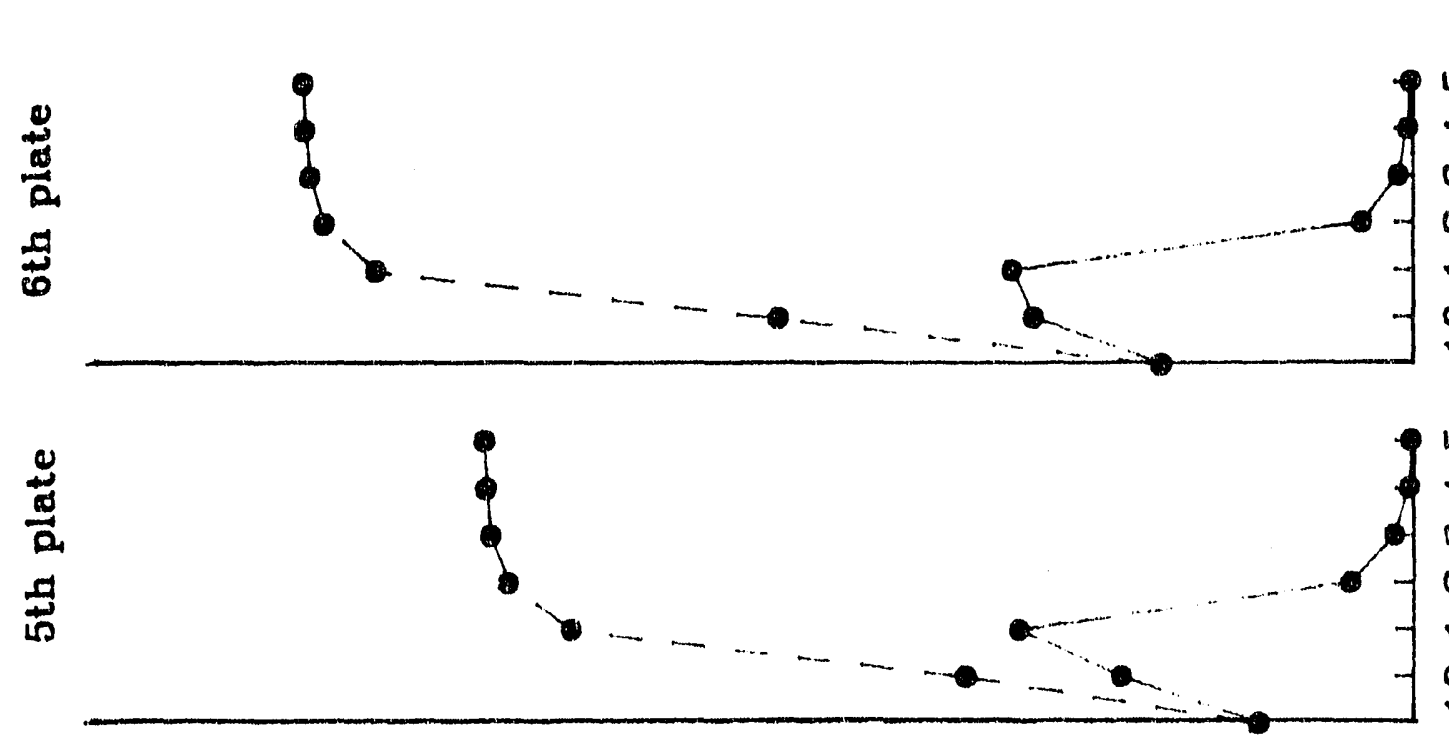

$\frac{0}{20}$

0
0
0
0
0
0

$-$
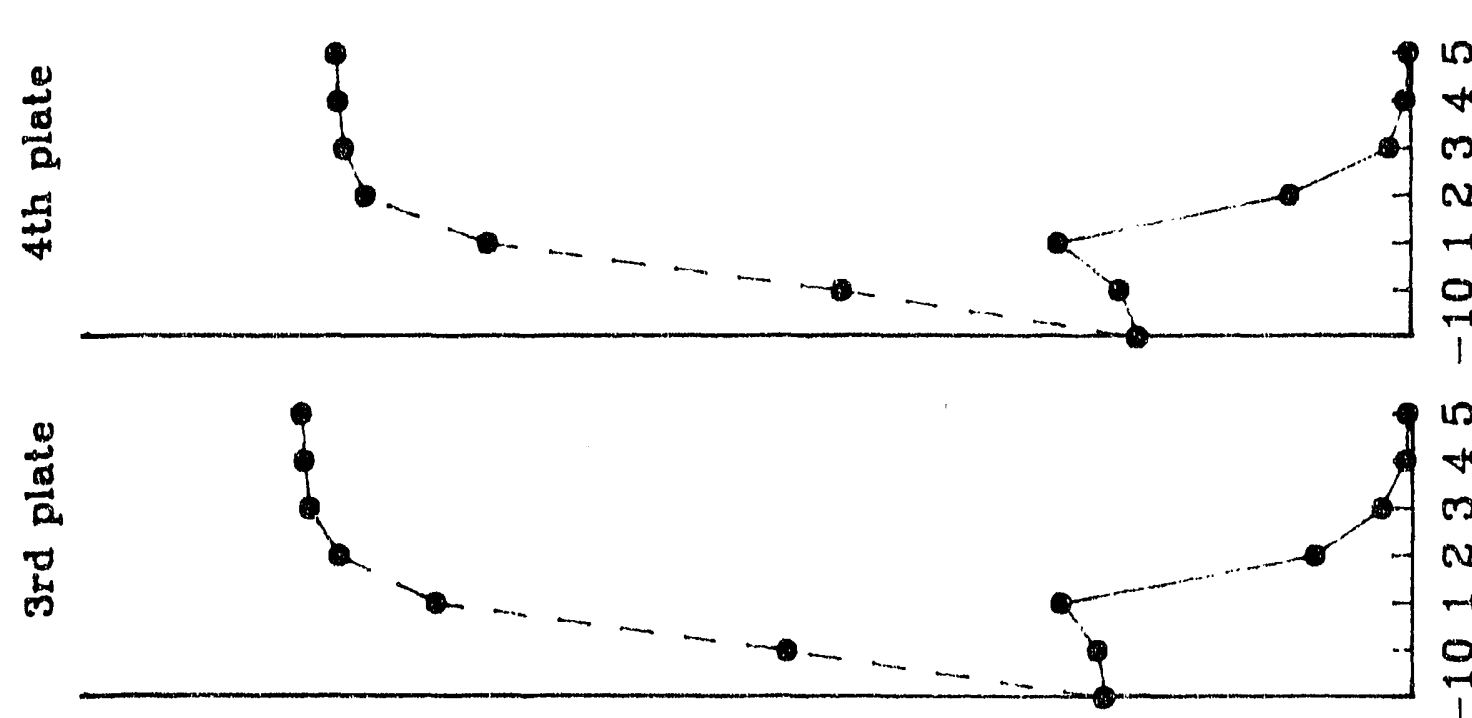

ก

듬

4

in m

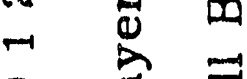

$\stackrel{1}{1}$

岁范

a 4

1

$\therefore \stackrel{5}{n}$

西

믈

U

잉
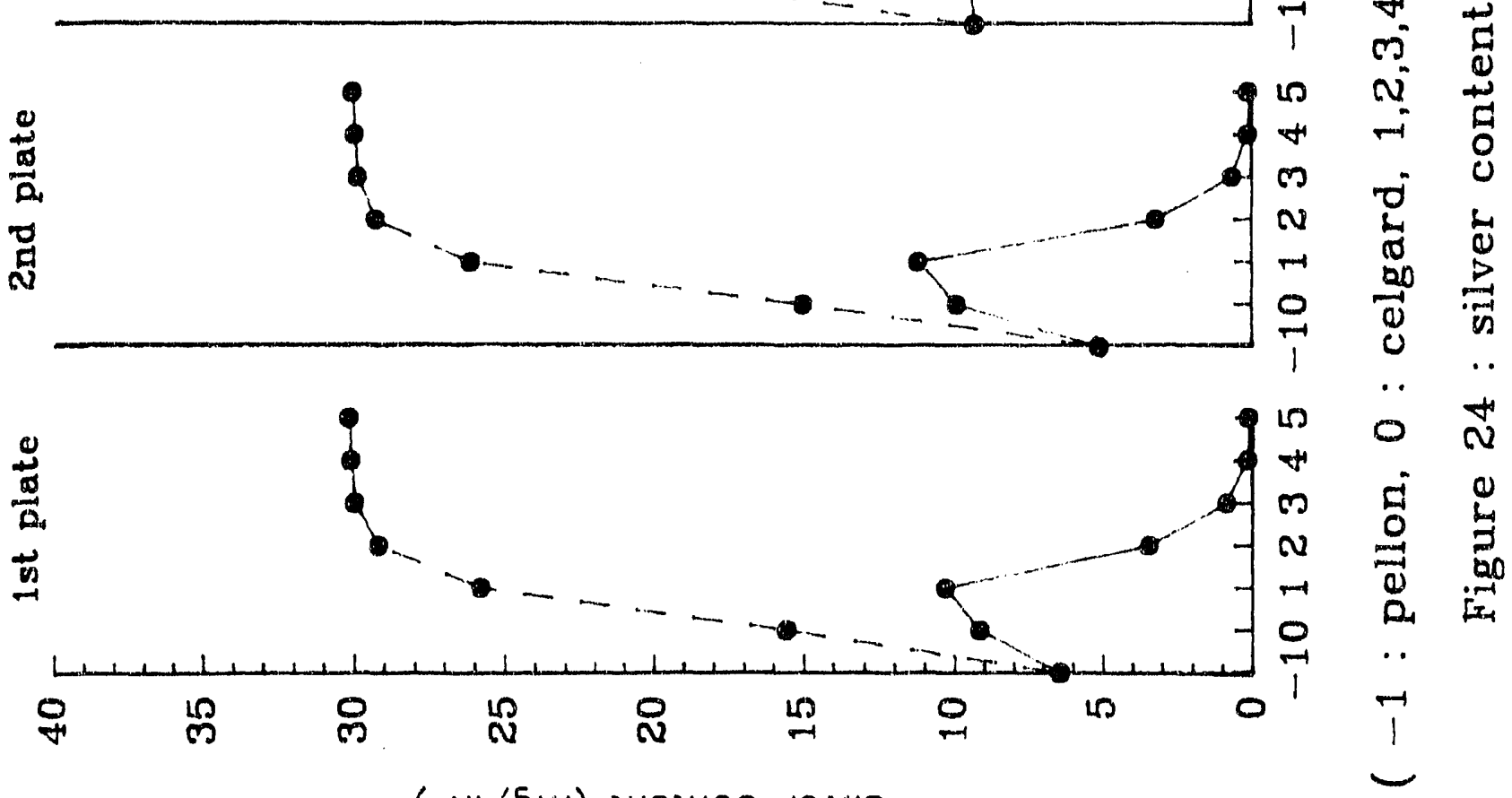

${ }_{\tau}(u ! / 5 m)$ juajuos san!!s 


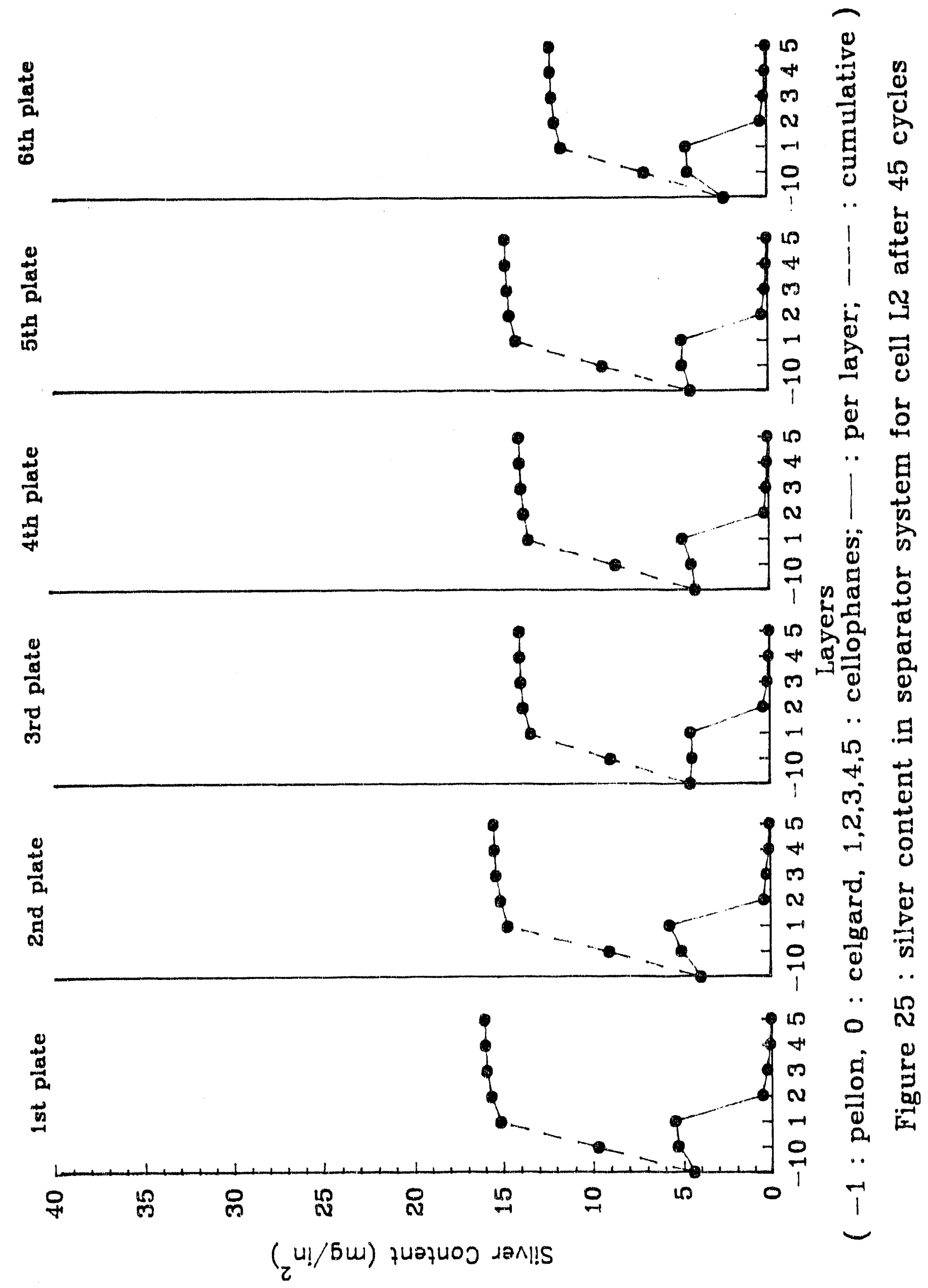




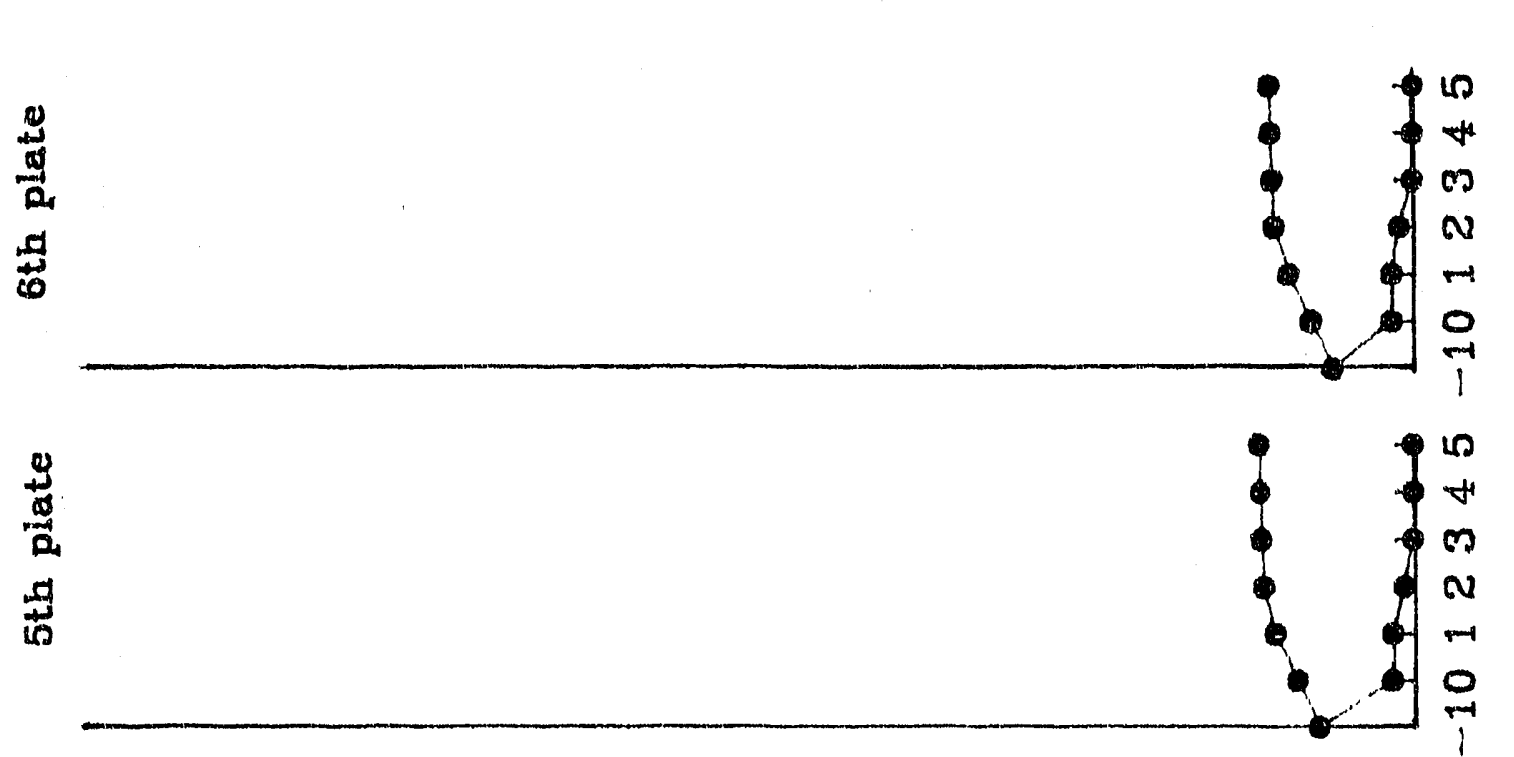

㟧
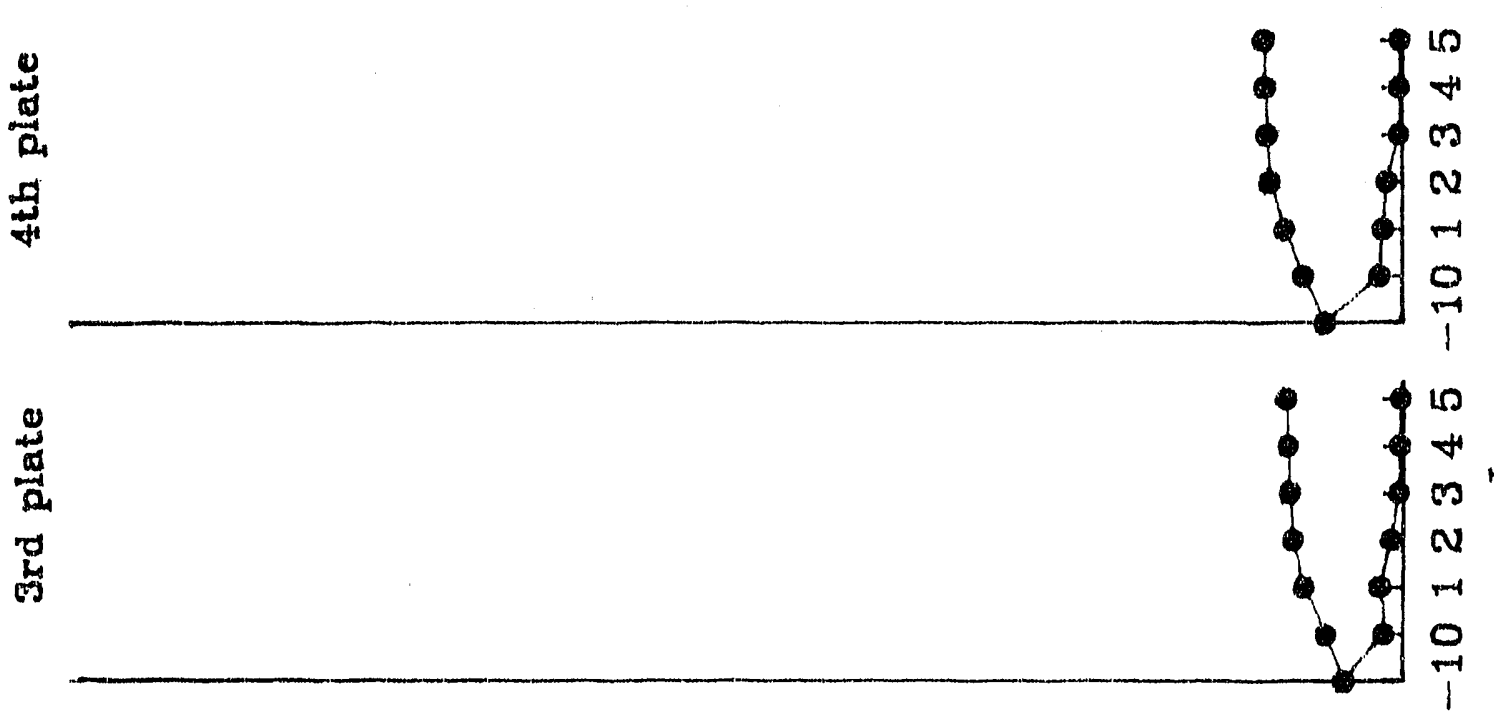

岂

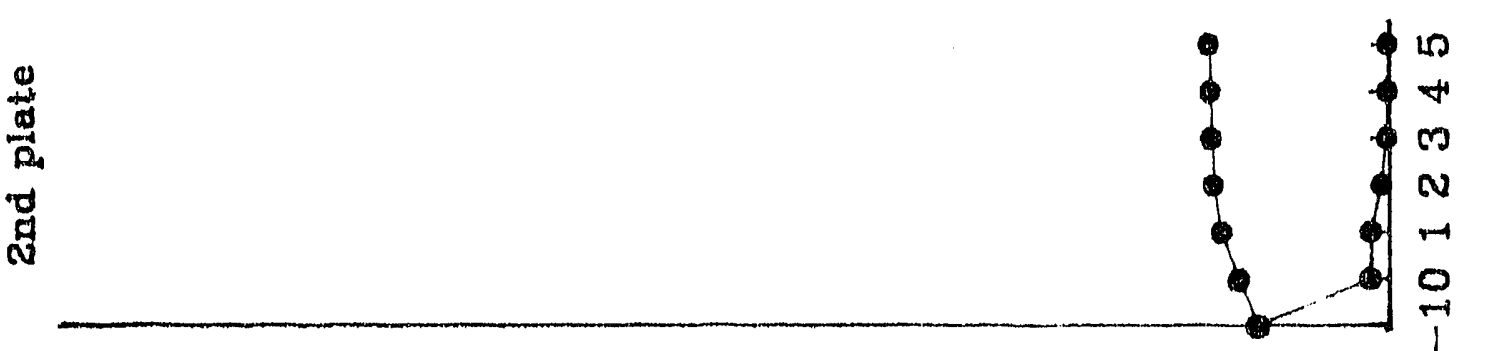

is

需

出

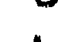

(a) 0

.

$E$

in

$\Phi$

u

造圈

엄

4

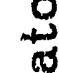

4

0

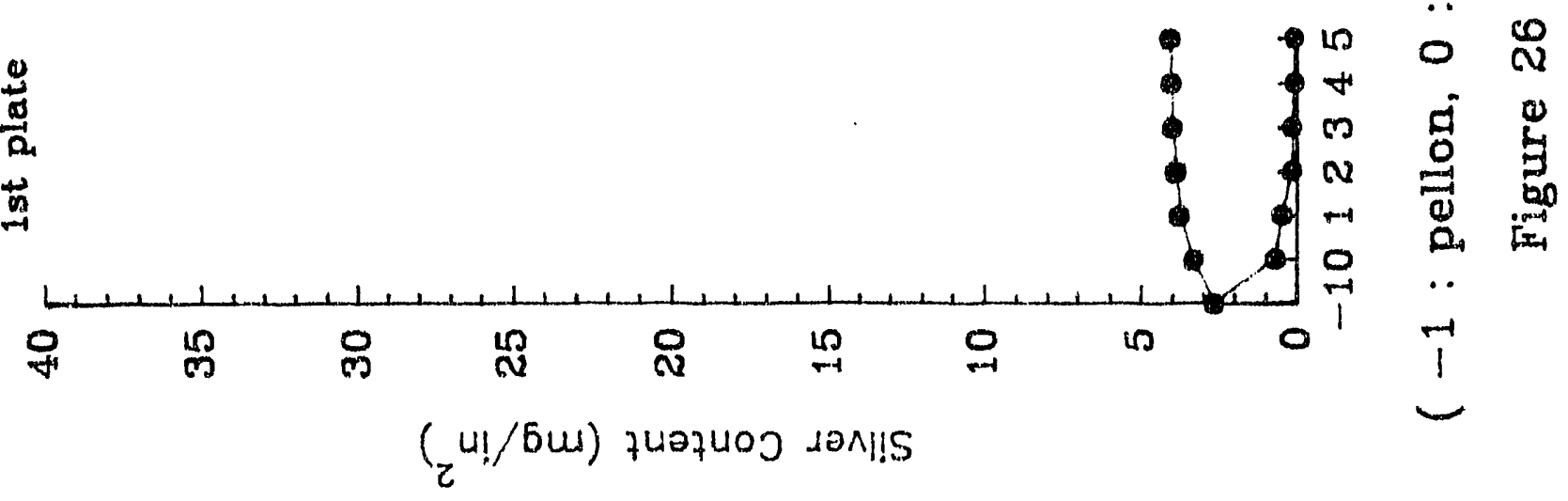




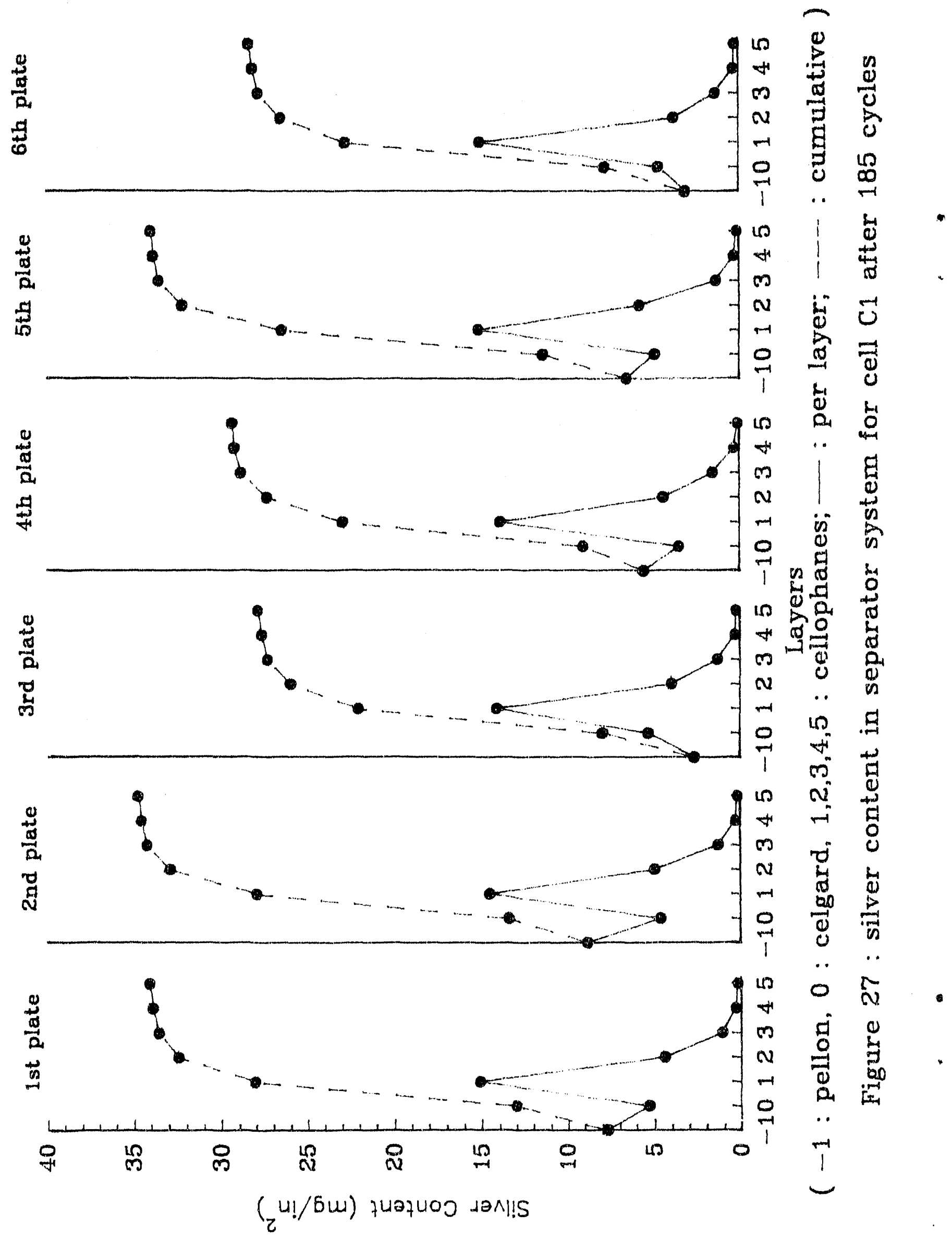



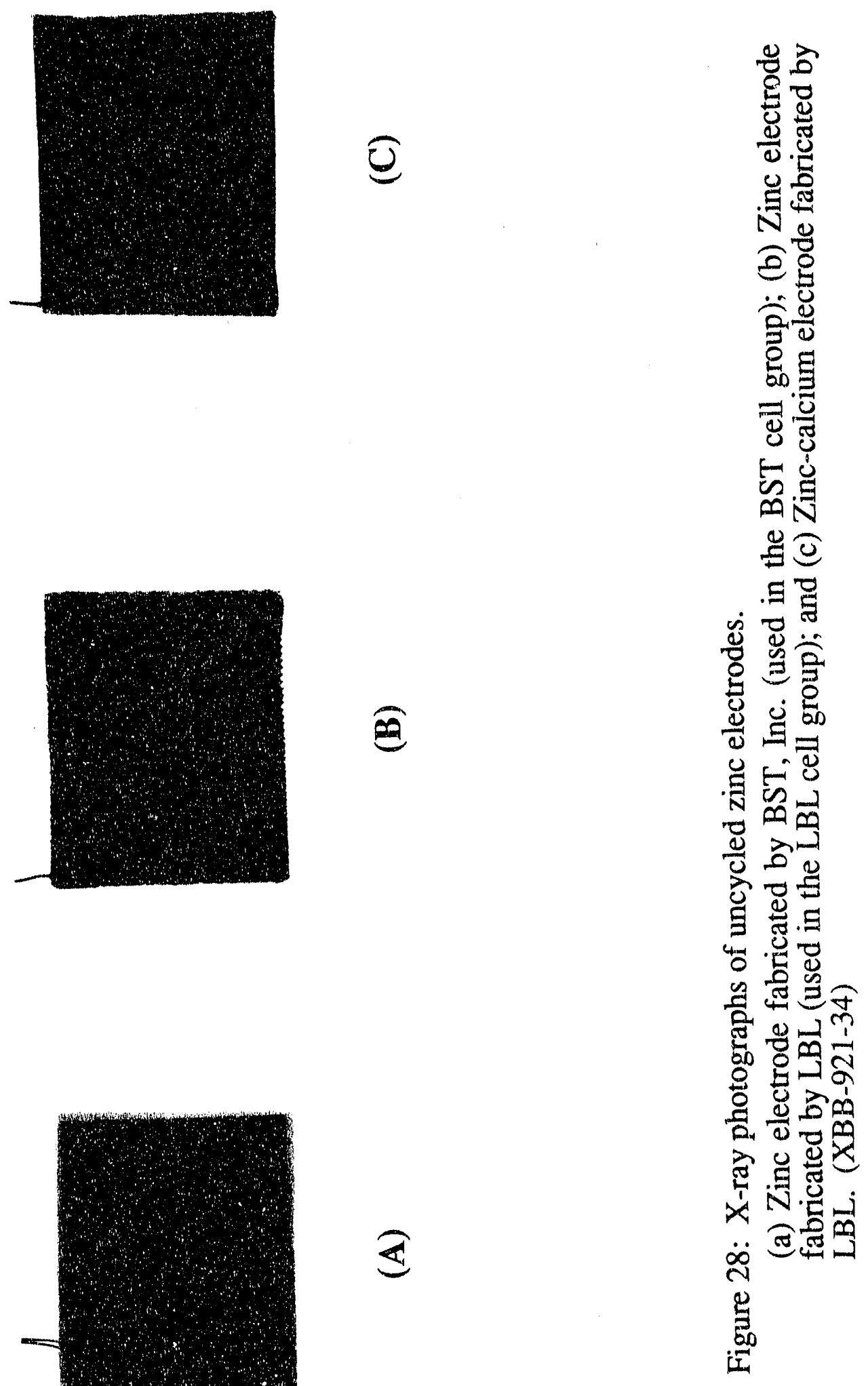

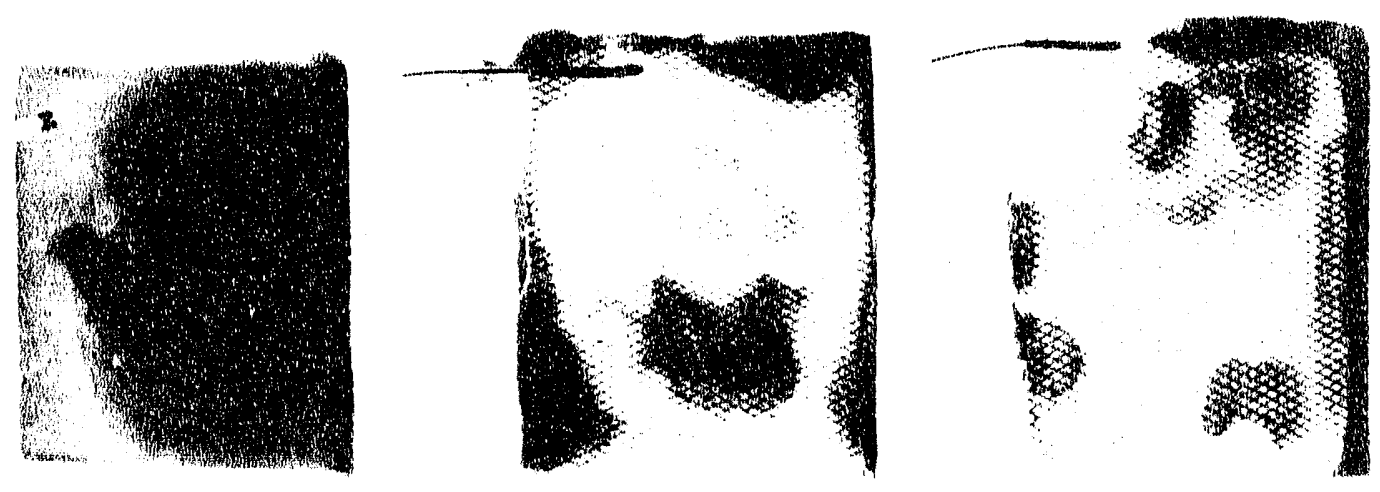

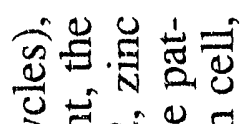

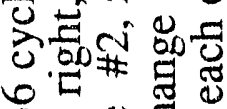

용

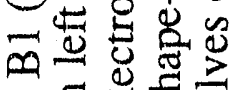

$\stackrel{0}{0} \frac{0}{0} \frac{\pi}{0}$

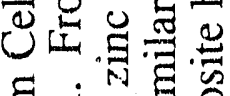
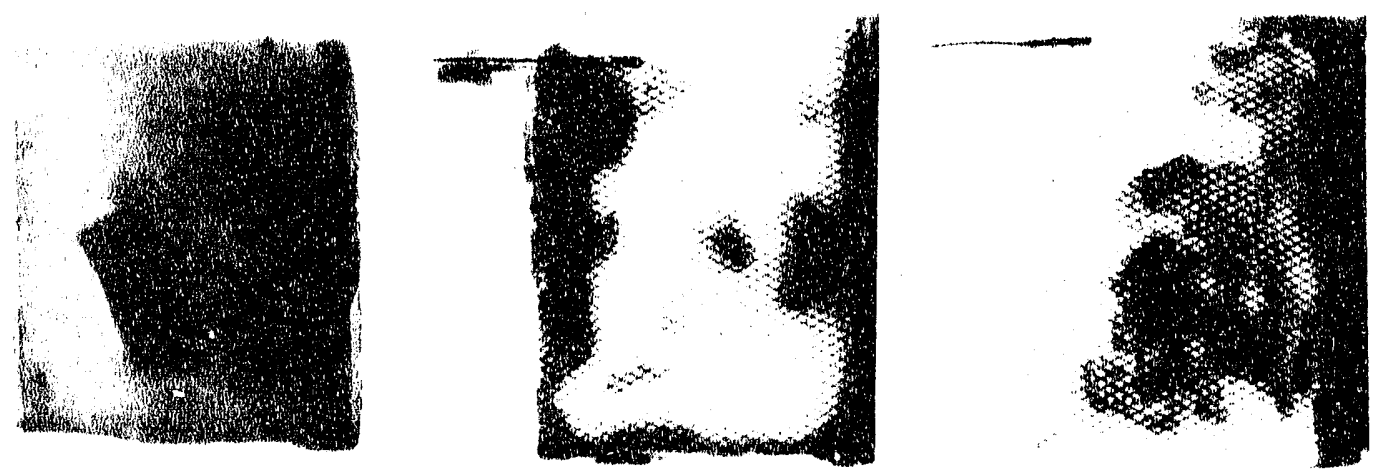

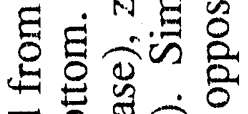

Ð0

世 070

공워웡

记

E

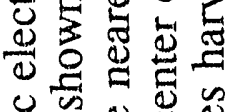

的出 \&
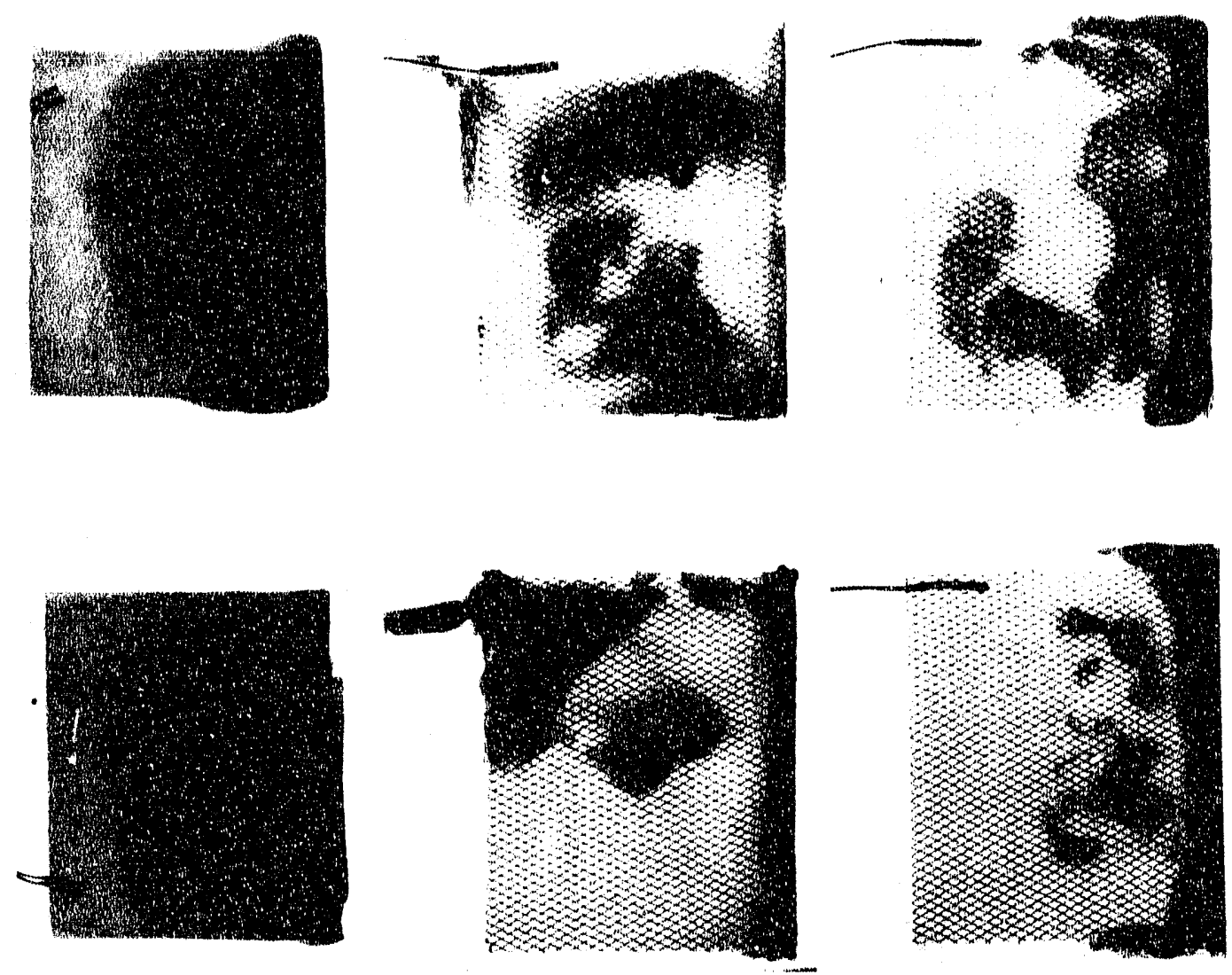

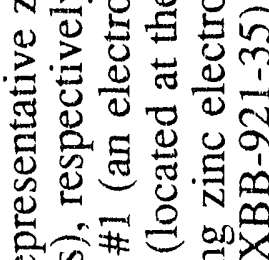
媳

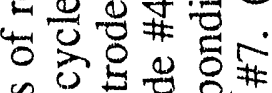

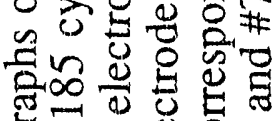

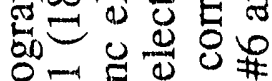

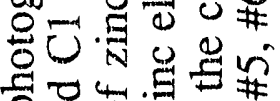

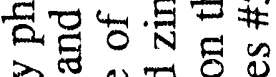
空语完

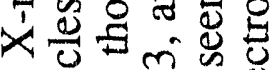

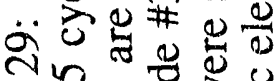
궈용 包要的思

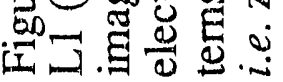

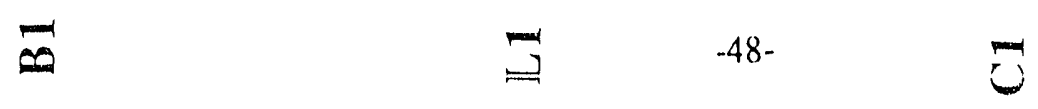



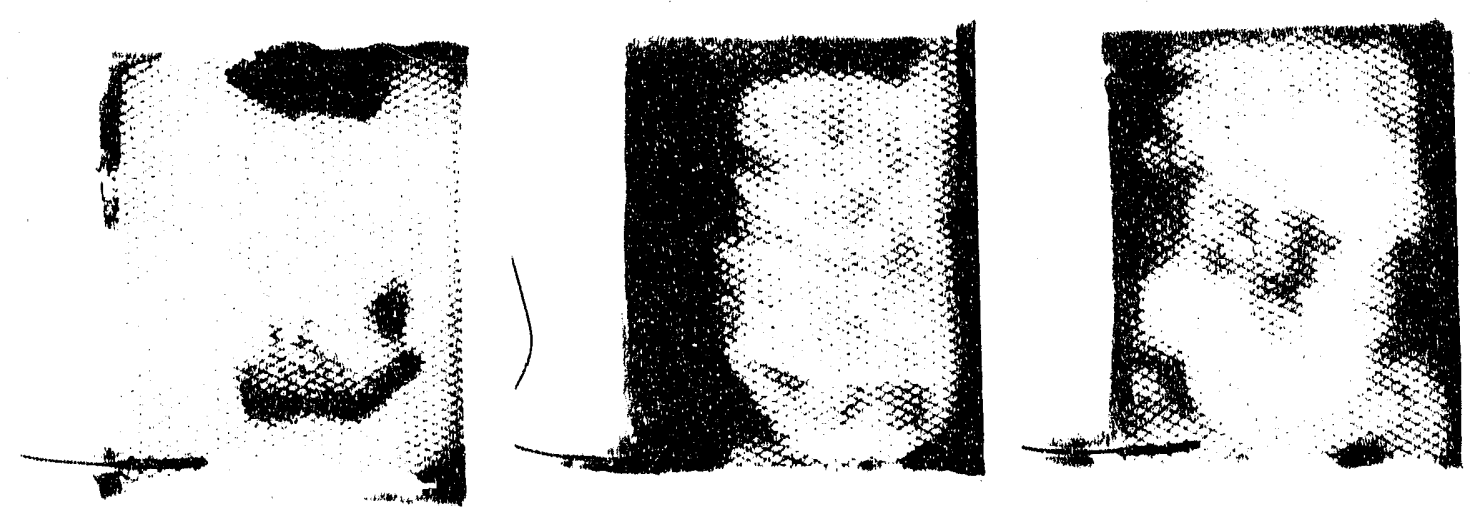

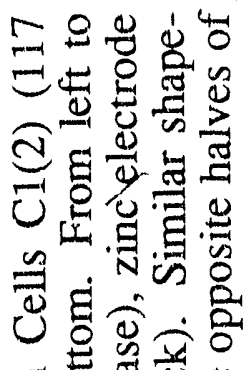
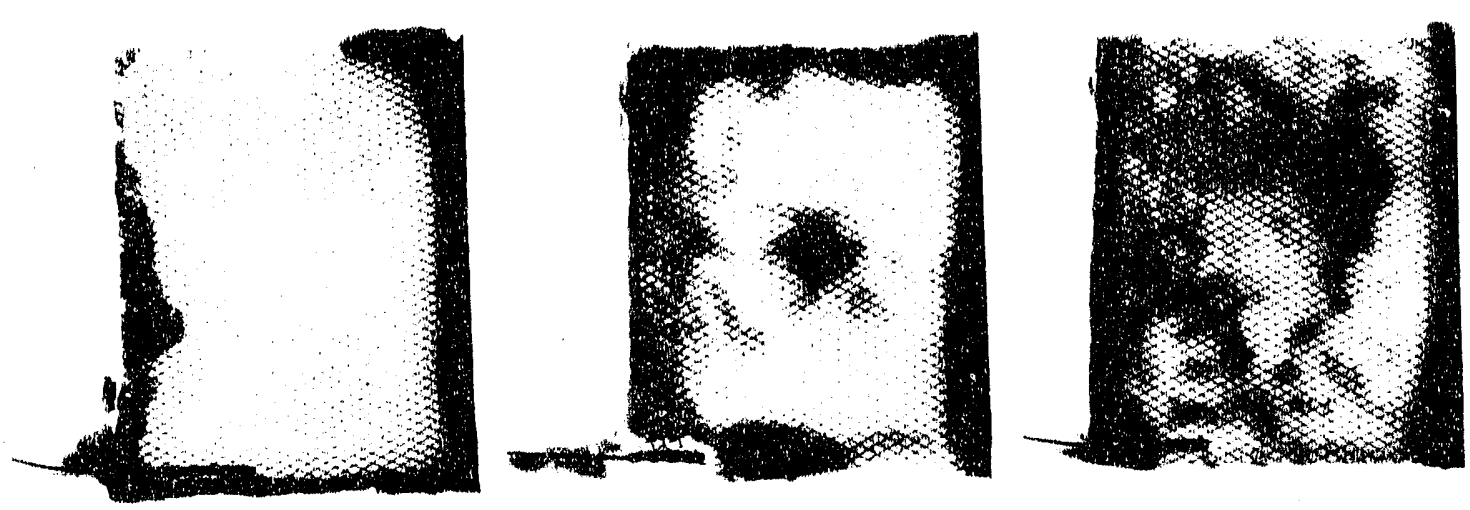

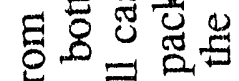

次 $\overline{0} \overline{0}$

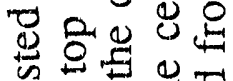

出

起苟范岕

解氖

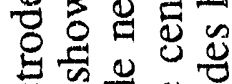

的苋 范

这运总

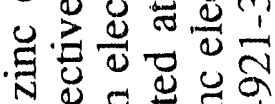

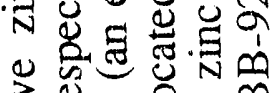
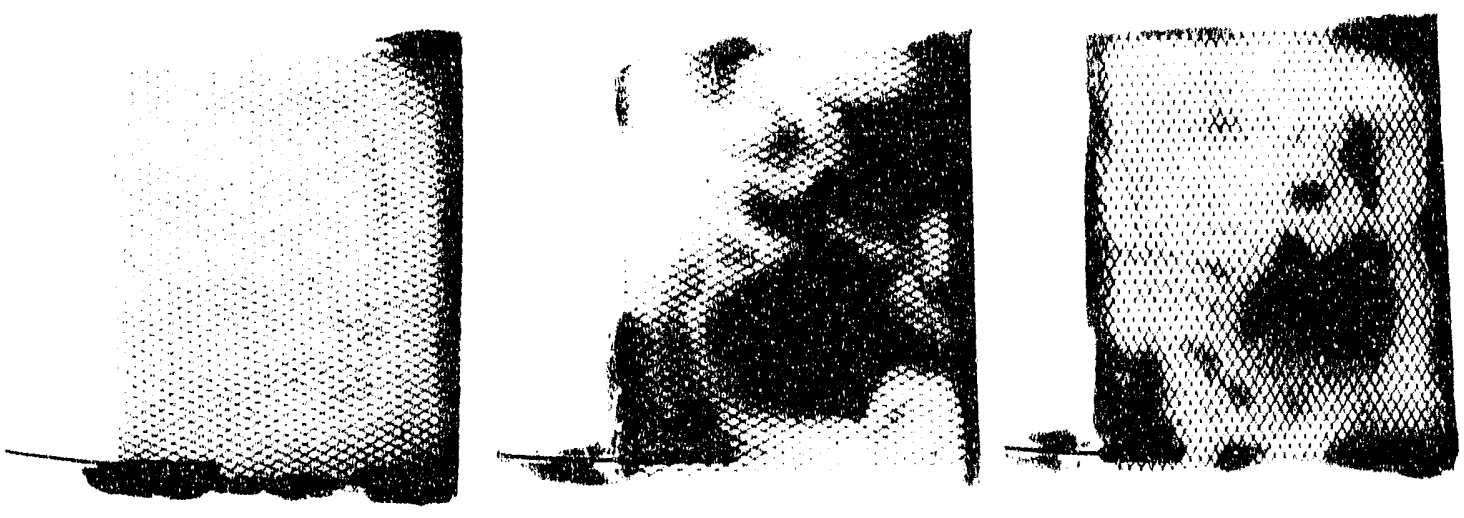

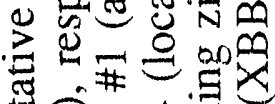

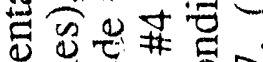
号㤩 它式 勾选志志 40

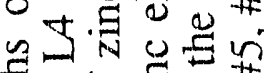

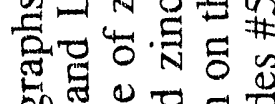

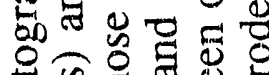

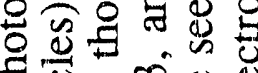

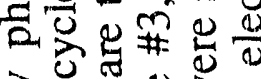
密的数

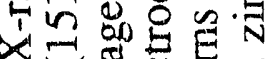

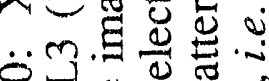
에

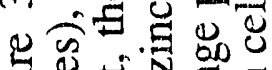

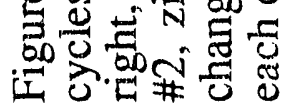
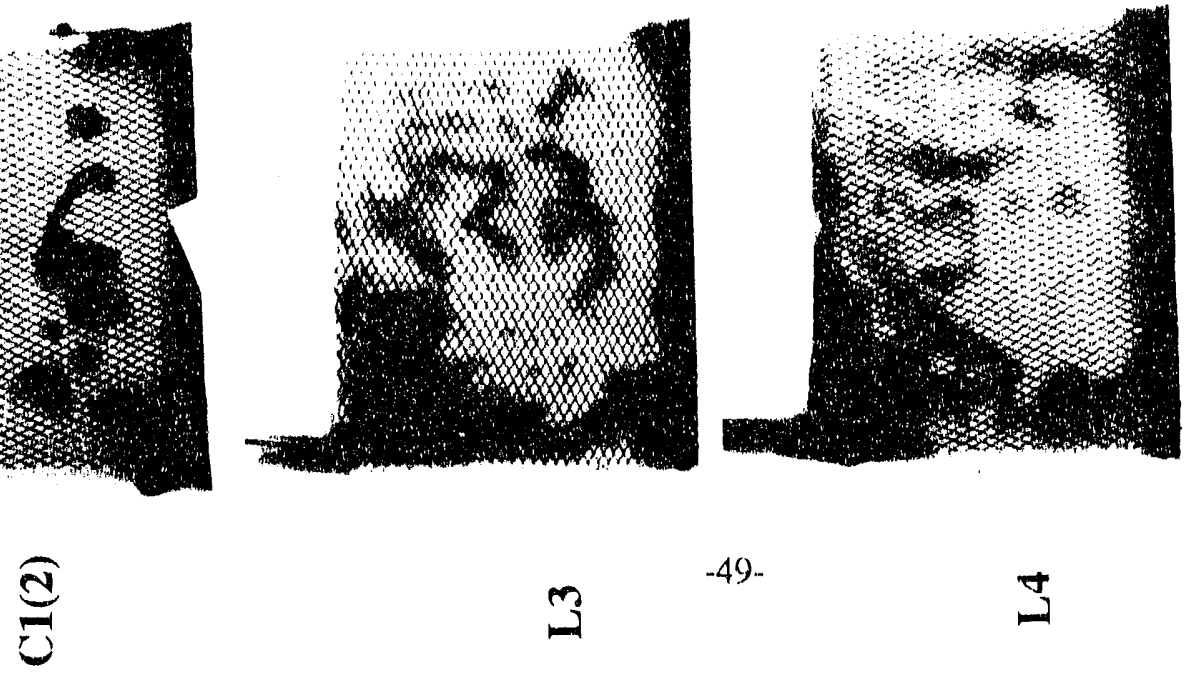


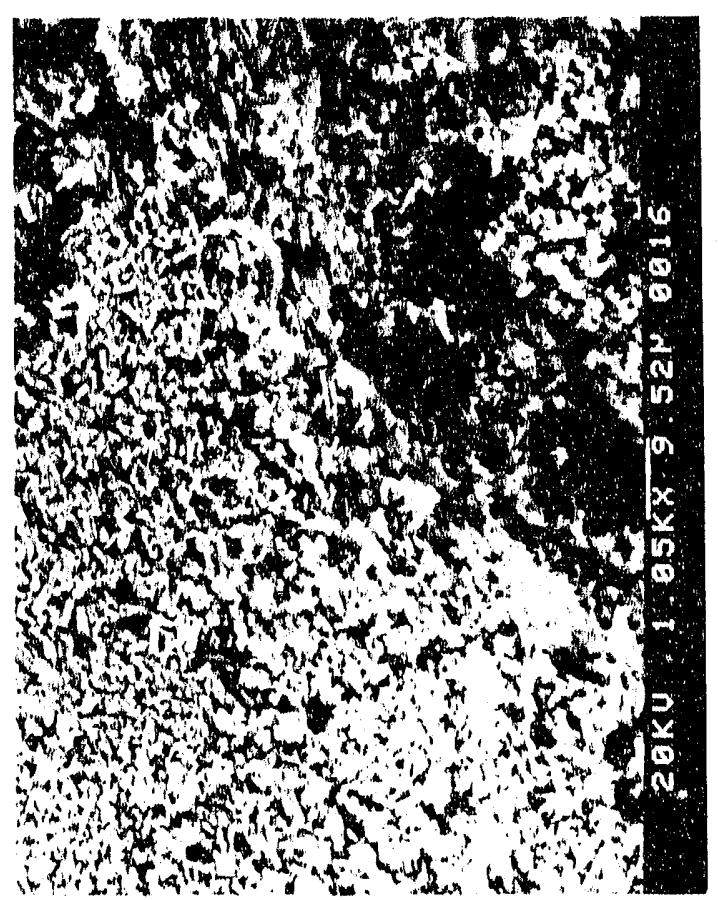

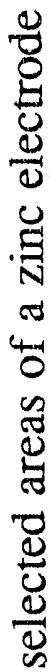

$=$

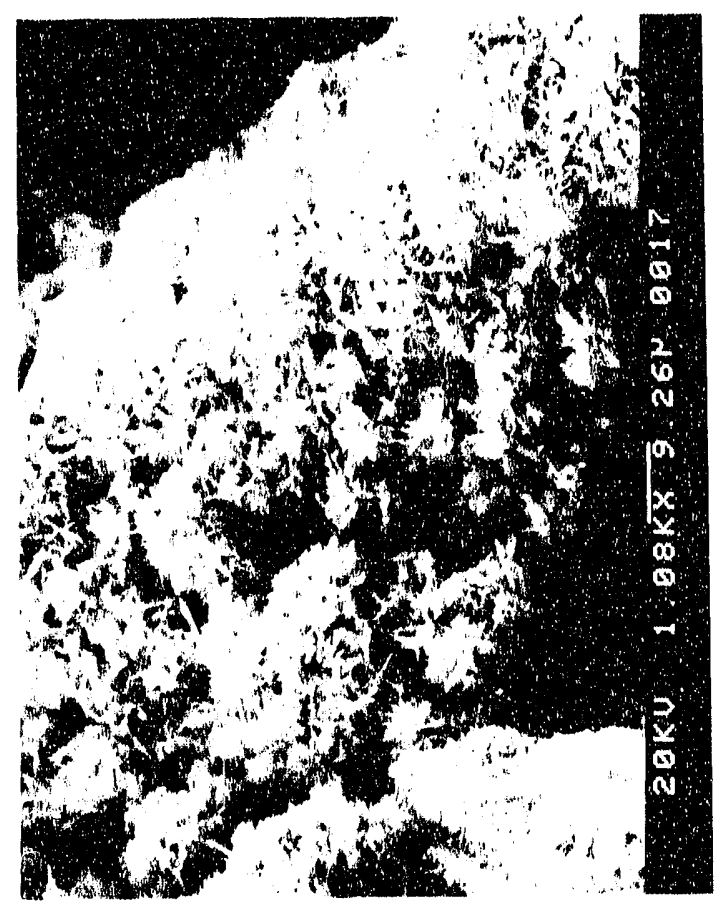

ปั)

ป

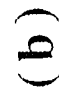

5

.

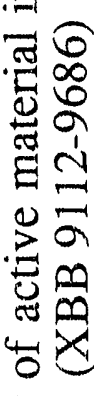

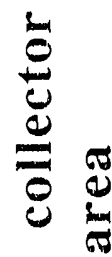

$\Xi$

प्रिल

$\exists-$

음

3

تِ

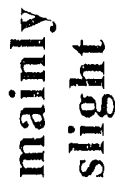

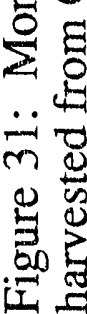

है 


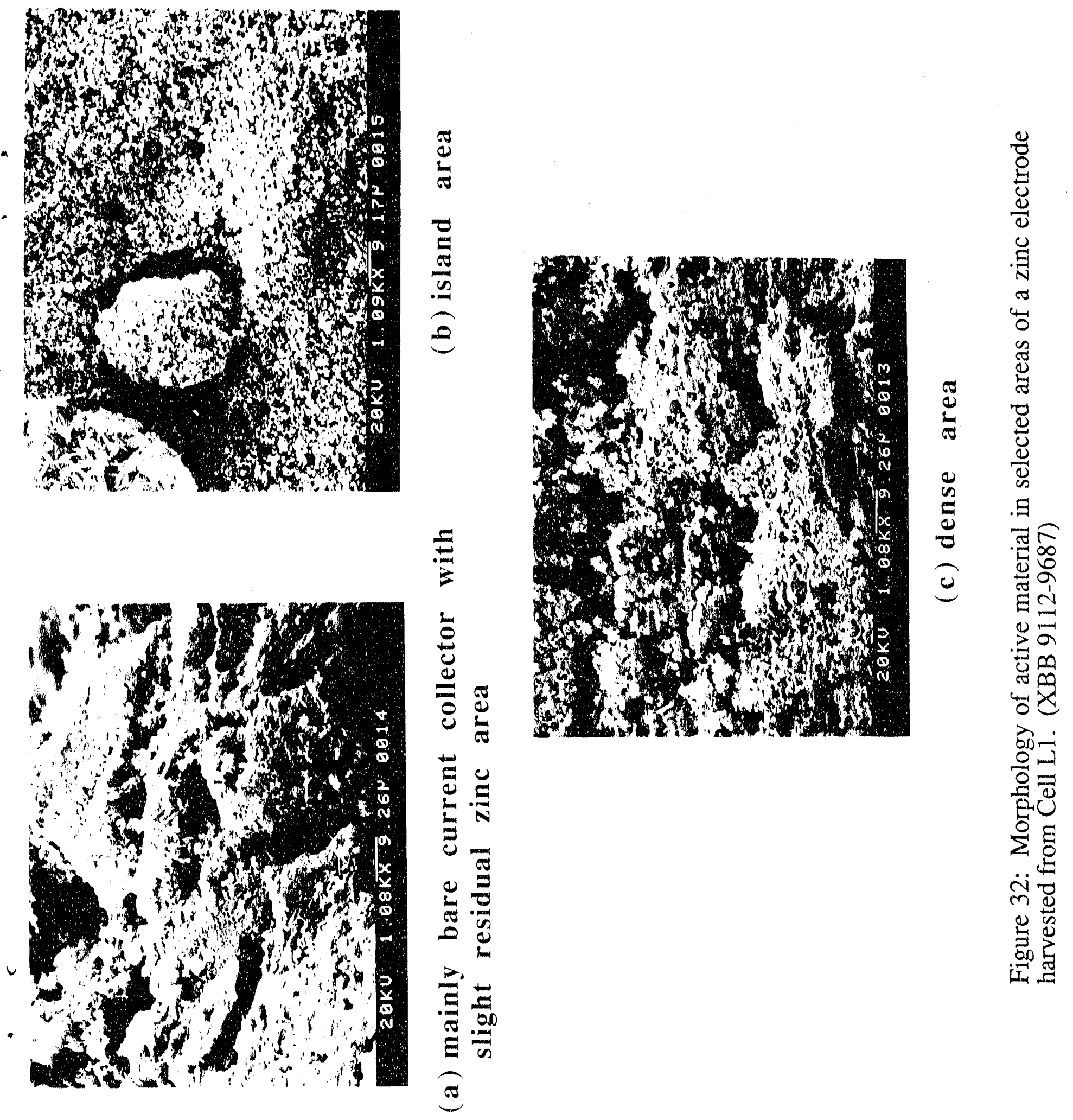




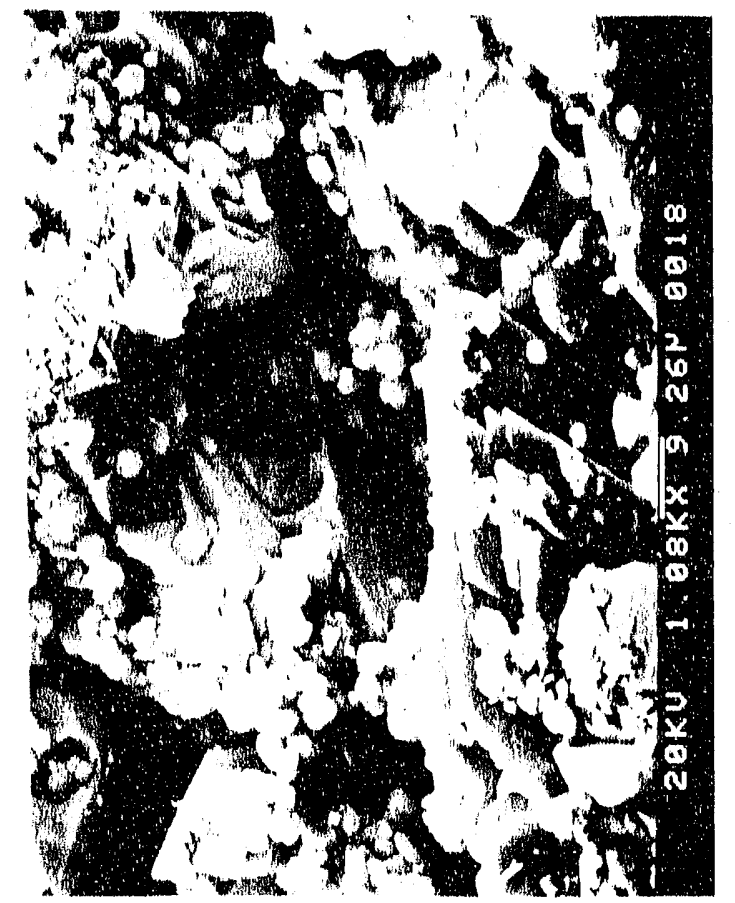

$\sqrt{2}$

曷

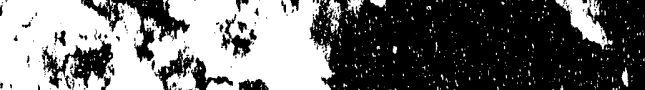

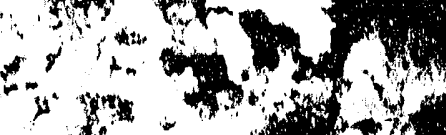

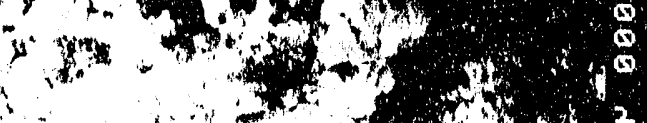

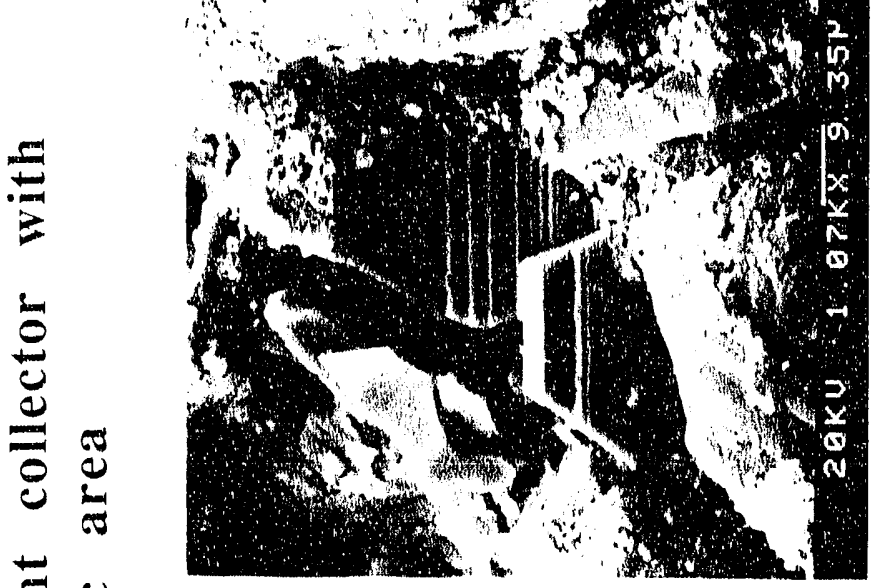

- 1 范

$\begin{array}{ll}0 & =10 \\ 0 & =\frac{\pi}{0} \\ 0 & \frac{\pi}{0}\end{array}$

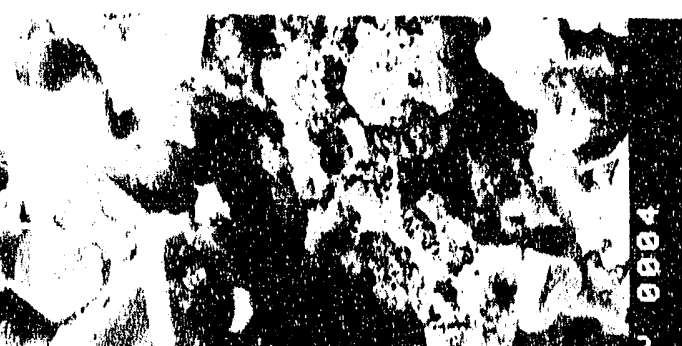

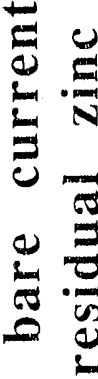

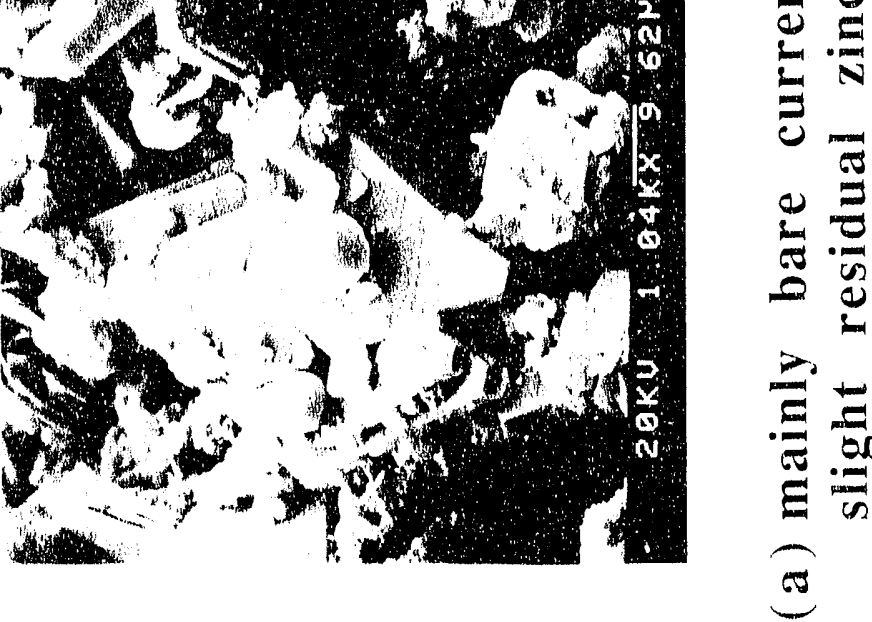

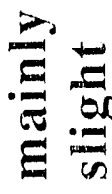

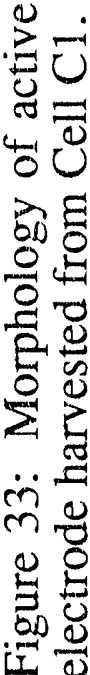


